\title{
23 Current Trends in Chondrichthyes Experimental Biology
}

\author{
Yasmine Lund-Ricard and Agnès Boutet
}

\section{CONTENTS}

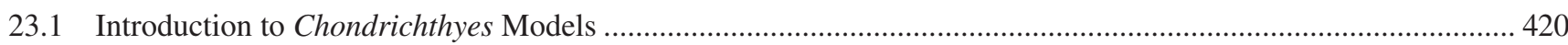

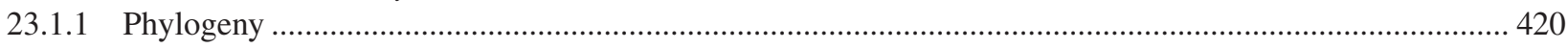

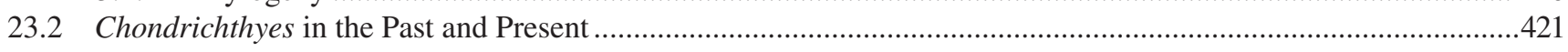

23.2.1 The Rise of Chondrichthyes as Models in Experimental Biology ..............................................................421

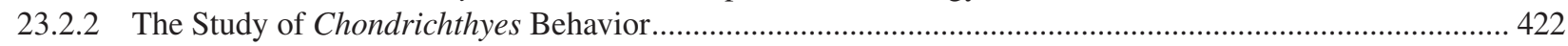

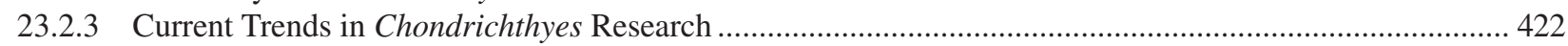

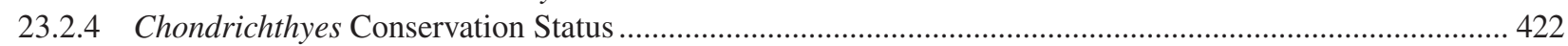

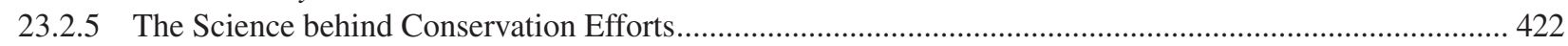

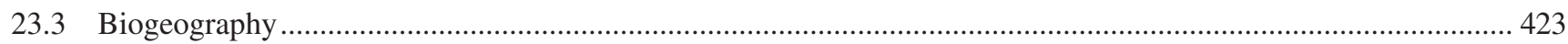

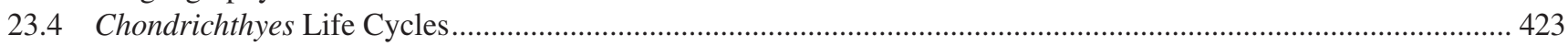

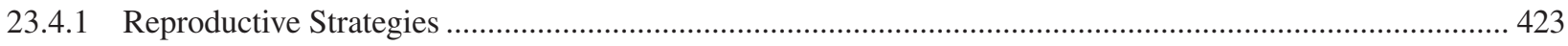

23.4.2 Chondrichthyes Species in Developmental Biology ........................................................................ 423

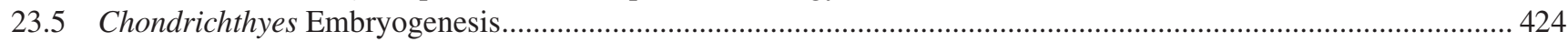

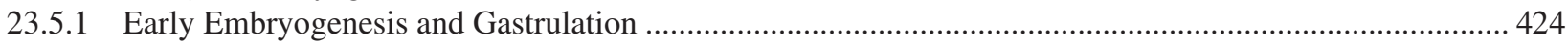

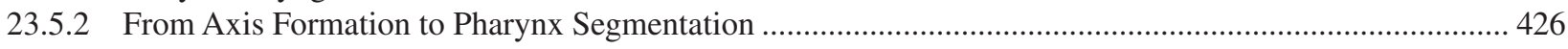

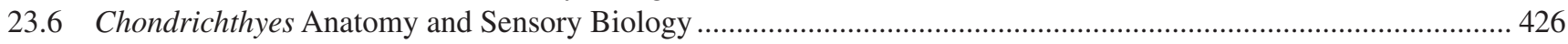

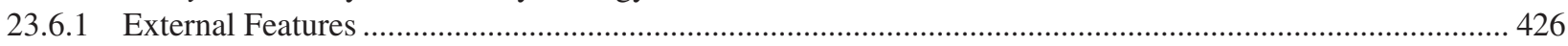

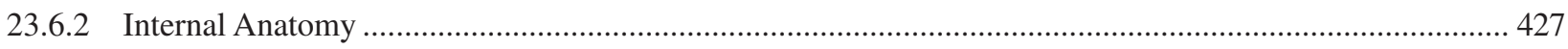

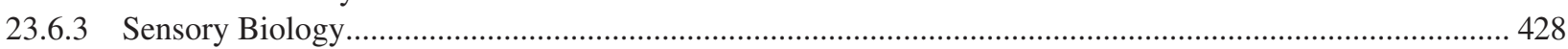

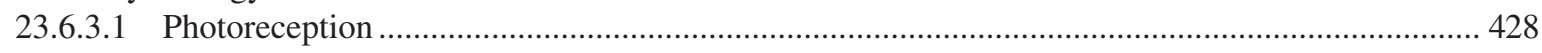

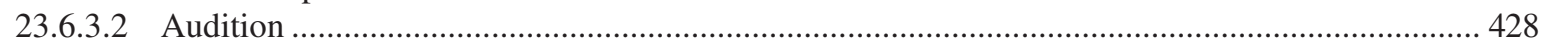

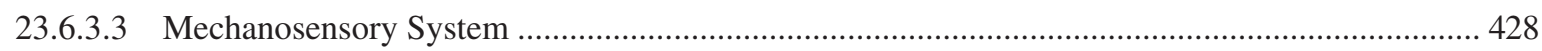

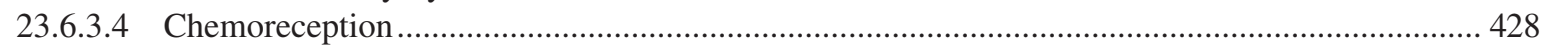

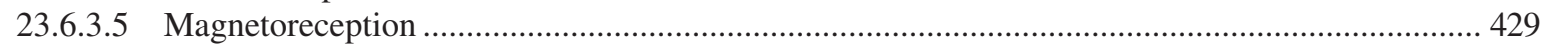

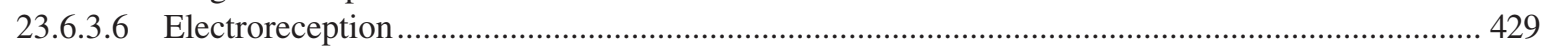

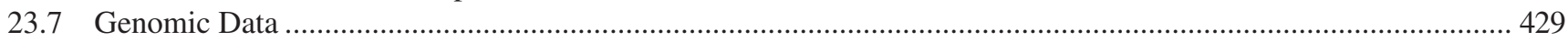

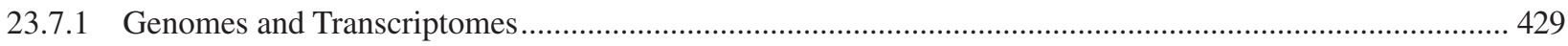

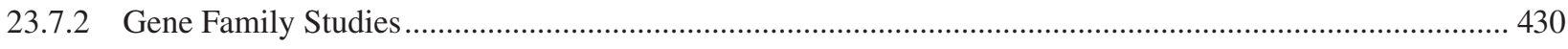

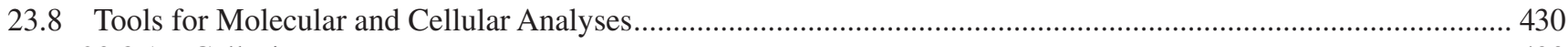

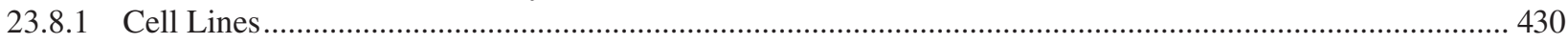

23.8.2 Descriptive and Functional Approaches ..........................................................................................431

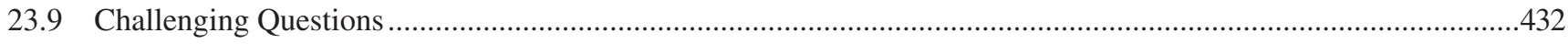

23.9.1 Endogenous Chondrichthyes Molecules for Biomedical Applications ..................................................432

23.9.1.1 Molecules Displaying Antibiotic Activity ................................................................................432

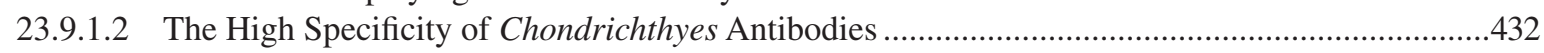

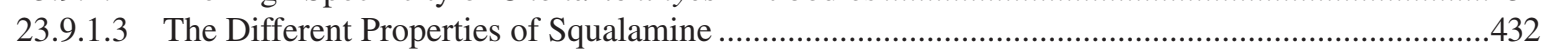

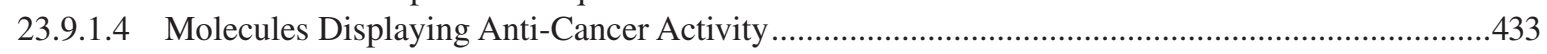

23.9.2 Evo-Devo Studies in the Search for the Origin of Skeleton and Brain Asymmetries .................................433

23.9.2.1 Endoskeleton and Bone-Like Tissue in Chondrichthyes .............................................................433

23.9.2.2 Exoskeleton (Teeth and Dermal Denticles) in Chondrichthyes .................................................... 434

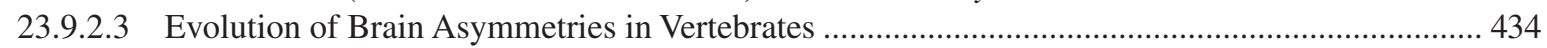

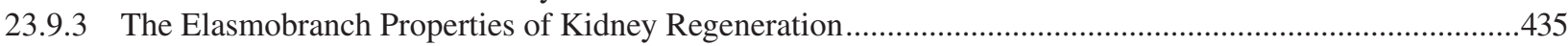

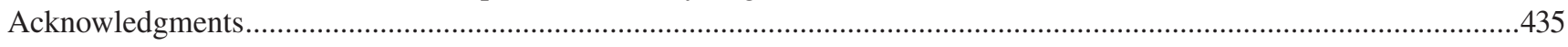

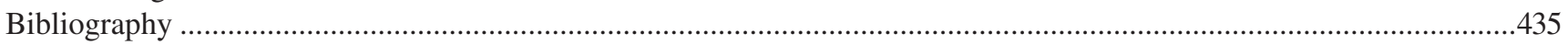




\subsection{INTRODUCTION TO CHONDRICHTHYES MODELS}

\subsubsection{Phylogeny}

Chondrichthyes (cartilaginous fish) belong to gnathostomes (jawed vertebrates) and constitute the sister group of Osteichthyes (bony vertebrates). This monophyletic group diverged from a common ancestor with the Osteichthyes lineage about 420 million year ago (mya) (Brazeau and Friedman 2015) and occupies a pivotal position in gnathostomes. Within the Chondrichthyes class, there exists two sub-classes, Elasmobranchii (sharks, rays, skates and sawfish) and Holocephali (chimeras) (see Figure 23.1 to follow the description of Chondrichthyes phylogeny). The earliest trace of Holocephali can be found around 420 mya (Inoue et al. 2010). Holocephali include a single surviving order, Chimaeriformes (chimeras), with 39 extant species. One popular chimera is Callorhinchus milii, also known as the Australian ghost-shark. The elasmobranch subclass includes more than 1,000 species of sharks, skates and rays. Elasmobranchs are composed of eight orders of Selachii (modern sharks) and four orders of Batoidea (rays, skates, guitarfish and sawfish). Figure 23.1 recapitulates the main Chondrichthyes groups and mentions the species that will be discussed in this chapter. It is interesting to note that the Chondrichthyes group has survived the five mass extinctions over the last 400 million years.

Because of their phylogenetic position, Chondrichthyes have been used to shed light on the origin of gnathostomes. How the last common ancestor of all gnathostomes looked like is the subject of intense debate. Beside Chondrichthyes and Osteichthyes, jawed vertebrates comprise two paraphyletic groups of extinct animals, placoderms and acanthodians, whose fossils help specify the relationship of this common ancestor with cartilaginous and bony fish. Morphological data from fossil brain cases (Davis et al. 2012; Giles et al. 2015) and dermal skeletons (Zhu et al. 2013) have been used to build these hypotheses. In the study conducted by Davis et al. (2012), modern jawed vertebrates are proposed to be the result of the diversification of Osteichthyes away from an ancestral form similar to Chondrichthyes, to which acanthodians belonged. A study analyzing a shark-like

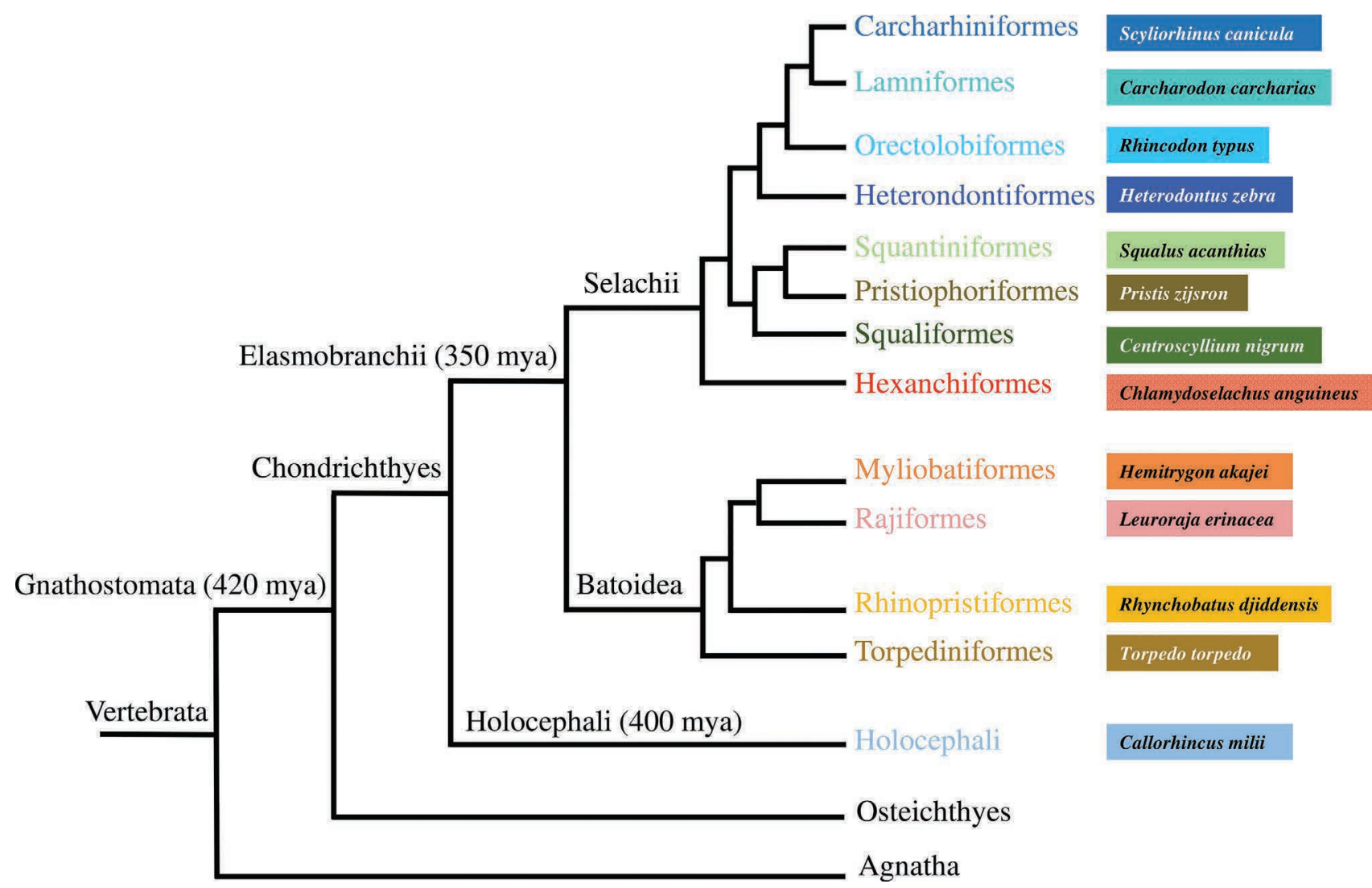

FIGURE 23.1 Phylogenic classification representing Chondrichthyes within vertebrates. Terminal clades are orders (Lamniformes, Rajiformes .. .), and each order is illustrated with an example species. Chondrichthyes comprise Elasmobranchii and Holocephali. Elasmobranchii include Selachii and Batoidea. The Selachii superorder encompasses eight orders: Carcharhiniformes (ground sharks), Heterodontiformes (bullhead sharks), Hexanchiformes (frilled and cow sharks), Lamniformes (mackerel sharks), Orectolobiformes (carpet sharks), Pristiophoriformes (sawsharks), Squaliformes (dogfish sharks) and Squatiniformes (angel sharks). The Batoidea superorder includes Myliobatiformes (stingrays and relatives), Rajiformes (skates and guitarfish), Torpediniformes (electric rays) and Rhinopristiformes (sawfish). 
fossil concluded that the ancestral gnathostome condition for branchial arches was Osteichthyes-like (Pradel et al. 2014). Another study described an unexpected contrast between the endoskeletal structure in Janusiscus (an early Devonian gnathostome) and its superficially Osteichthyeslike dermal skeleton (Giles et al. 2015). The evolutionary history of jawed vertebrates is still debated, as newly uncovered fossils of early gnathostomes show unseen combinations of primitive and derived characters (Patterson 1981). For a detailed recent discussion about the evolution of jawed vertebrates, the reader can refer to the review from Brazeau and Friedman (2015).

\subsection{CHONDRICHTHYES IN THE PAST AND PRESENT}

Historically, scientific knowledge about Chondrichthyes remained limited compared to other vertebrates. Indeed, studying highly mobile animals in vast marine environments remained a challenge until the proper technologies were developed (Castro 2017). In 1868, Jonathan Couch reported descriptions and drawings of 35 Chondrichthyes species in the book History of the Fishes of the British Islands (1863, Figure 23.2), which constitutes one of the first atlases of the group. This diverse class contains some of the first animal models in experimental biology.

\subsubsection{The Rise of Chondrichthyes as Models in Experimental Biology}

The earliest mention of Chondrichthyes by scientists dates back to Aristotle (Demski and Wourms 2013). His observations include i) the distinction between oviparous and viviparous modes of reproduction in sharks, skates and rays; ii) description of the female and male reproductive system; iii) description of the shark and skate egg case structure and observations on embryonic development; and iv) notes on breeding seasons and migrations for "pupping" (Demski and Wourms 2013). Wourms (1997) extensively described the history of the rise of both Osteichthyes and Chondrichthyes embryology. He argues that the progressive development of knowledge of teleosts and Chondrichthyes embryology during the 19th century drove the birth of modern descriptive embryology. This led to the rise of comparative embryology associated with evolutionary studies and then to the experimental and physiological study of development (Wourms 1997). For example, Kastschenko (1888) used catshark embryos (Scyliorhinus
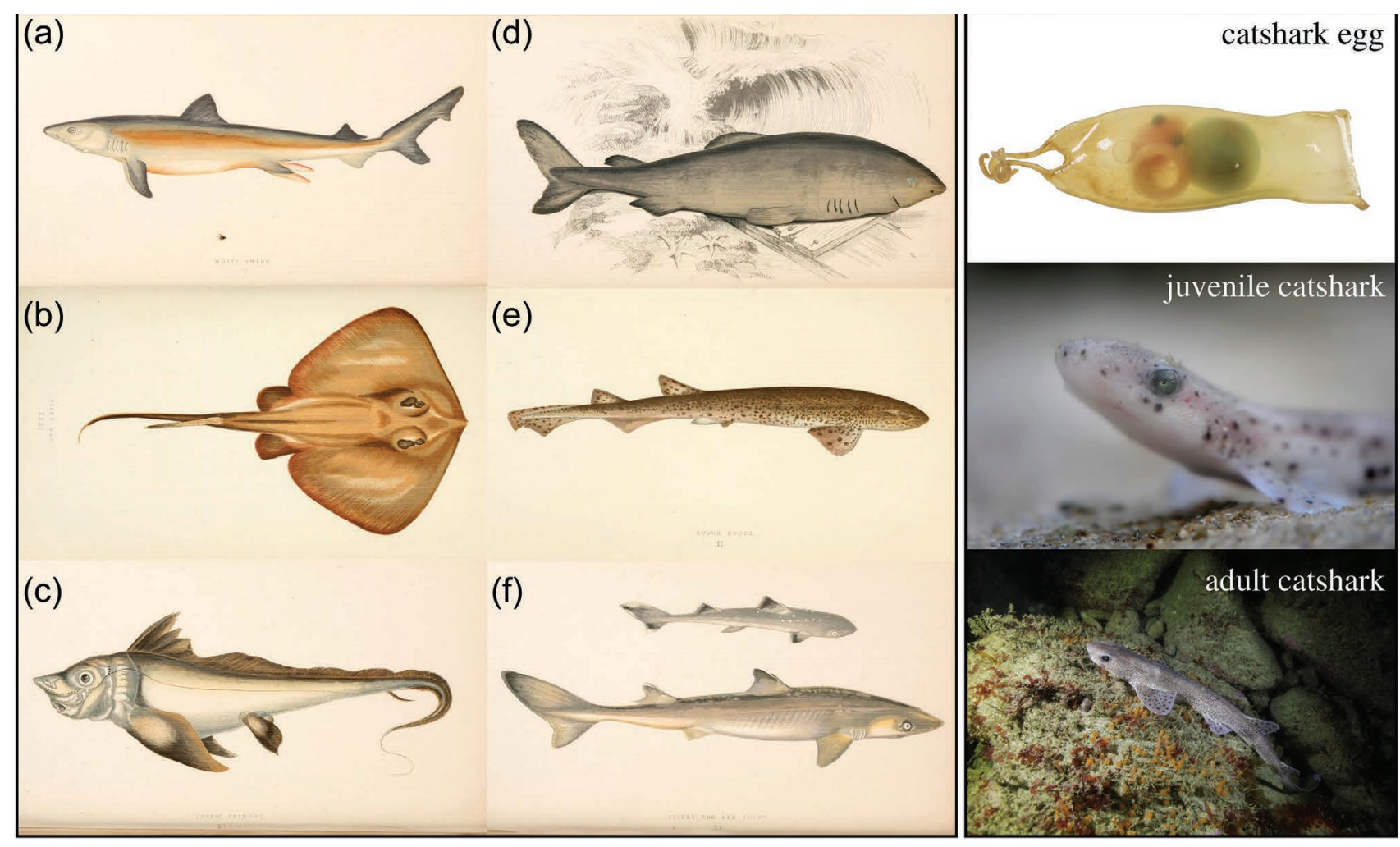

FIGURE 23.2 Drawings and pictures of Chondrichthyes species. (a-f) Drawings represent the white shark (a), sting ray (b), arctic chimera (c), Greenland shark (d), catshark (e) and picked dog (f). Right panel represents several steps of the catshark (Scyliorhinus canicula) life cycle: embryo, juvenile and adult stage. (From A History of the Fishes of the British Islands by Jonathan Couch, Vol I. 1868. Station Biologique de Roscoff (SBR) library collection and Biodiversity Heritage Library. Photos courtesy of @ Station Biologique de Roscoff, Wilfried Thomas.) 
canicula, Figure 23.2) as experimental models to test a developmental theory.

\subsubsection{The Study of Chondrichthyes Behavior}

The first reported studies on Chondrichthyes behavior emerged later. The initial studies on shark behavior include those carried out by Sheldon $(1909,1911)$ and by Parker (1914). The focus of these studies was the influence of the eyes, ears and other allied sense organs on the movements of the dogfish Mustelus canis. Remarkably, a military project entitled "Project Headgear" (1958-1971) conducted experiments in which sharks were trained to carry explosives. The details of this project have never been released. With increasingly sophisticated technology, the themes addressed in behavioral research have widened, and an array of studies can be found (Tricas and Gruber 2001; Sundström et al. 2001; Kelly et al. 2019; Gardiner 2012; Myrberg 2003; Gruber and Myrberg 1977; Hammerschlag 2016; Aidan et al. 2005). As the field of animal cognition expands, social learning in lemon sharks (Guttridge et al. 2013); tool use in batoids (Kuba et al. 2010); learning, habituations and memory in a benthic shark (Kimber et al. 2014); and spatial memory and orientation strategies in stingrays (Schluessel and Bleckmann 2005) have helped build a picture of Chondrichthyes cognitive functions. Schluessel (2015) reviewed the evidence for cognitive abilities in elasmobranchs.

\subsubsection{Current Trends in Chondrichthyes Research}

Current trends in Chondrichthyes research were analyzed in a recent review (Shiffman et al. 2020). This review depicts the trends in research efforts over three decades (1985-2016) by analyzing the content of all the abstracts presented at the annual conferences of the American Elasmobranch Society (AES), the oldest and largest professional society for the scientific study and management of these fish (Shiffman et al. 2020). AES research was most frequently on movement/ telemetry, age and growth, population genetics, reproductive biology and diet/feeding ecology, with different areas of focus for different species or families. Certain biases exist in areas of investigations such as species "charisma" (e.g. white shark, Carcharodon carcharias), accessibility to long-term established field research programs (e.g. lemon shark, Negaprion brevirostris, and sandbar shark, Carcharhinus plumbeus) or ease of model maintenance for lab-based research (e.g. bonnethead shark, Sphyrna tiburo) (Shiffman et al. 2020). Nearly $90 \%$ of all described Chondrichthyes species have never been mentioned in an AES abstract, including some of the most threatened species in the Americas (Shiffman et al. 2020).

\subsubsection{Chondrichthyes Conservation Status}

Chondrichthyes are considered one of the most threatened vertebrate groups by the International Union for the
Conservation of Nature (IUCN) Red List (McClenachan et al. 2012; Dulvy et al. 2014; White and Last 2012). The threats faced by Chondrichthyes can be grouped into the effects of various fishing activities and of habitat loss (Dulvy et al. 2014; Jennings et al. 2008) and environmental degradation such as pollution (Lyons and Wynne-Edwards 2018). Alarmingly, sharks are subject to a global slaughter; shark products such as dried fins have high commercial value and a high exposure to international trade (Gross 2019). Human exploitation of Chondrichthyes is aggravated by certain life history traits, like low fecundity, the production of small numbers of highly precocious young, slow growth rates and late sexual maturity (Collin 2012). In 2020, a study showed that fishing exploitation in the Mediterranean might exert an evolutionary pressure toward early maturation in the catshark, Scyliorhinus canicula (Ramírez-Amaro et al. 2020). Additionally, sharks are considered at a relatively high risk for climate change (Cavanagh et al. 2005; Rosa et al. 2014). Indeed, climate change is already affecting ocean temperatures, $\mathrm{pH}$ and oxygen levels. How ocean warming, acidification, deoxygenation and fishery exploitation may interact to impact Chondrichthyes populations is yet to be determined (Sims 2019; Rosa et al. 2017; Wheeler et al. 2020). The use of Chondrichthyes models in experimental biology must pay heed to conservation status.

\subsubsection{The Science behind Conservation Efforts}

Conservation efforts benefit from multidisciplinary approaches in assessing what conditions impact species survival. For example, quantifying distribution patterns and species-specific habitat associations in response to geographic and environmental drivers is critical to assessing risk of exposure to fishing, habitat degradation and the effects of climate change (Espinoza et al. 2014). Chondrichthyes extinction risk has been found to be determined by reproductive mode but not by body size (García et al. 2008). In this same study, extinction risk was highly correlated with phylogeny, and as such, the loss of species is predicted to be accompanied by a loss of phylogenetic diversity (García et al. 2008). Moreover, distribution patterns (Espinoza et al. 2014) ecosystem diversity (Boussarie et al. 2018), ecological context (Collin 2012) and behavior (Wheeler et al. 2020) are valuable for meaningful management and conservation. Behavioral differences within and between species, as well as the ecological context in which a species exists, can have important management implications. In an effort to combat the many threats Chondrichthyes face, several regions now have shark sanctuaries or have banned shark fishing - these regions include American Samoa, the Bahamas, Honduras, Dominican Republic, the Cook Islands, French Polynesia, Guam, the Maldives, Saba, St Marteen, New Caledonia, Bonaire, The Cayman Islands, the Marshall Islands, Micronesia, the Northern Mariana Islands and Palau (Bell 2018). These measures reveal that shark conservation has been understood as important. 


\subsection{BIOGEOGRAPHY}

Chondrichthyes occupy a variety of ecological habitats all around the world. While some are restricted to relatively specific zones (as a function of temperature, osmolality or resources), other Chondrichthyes have wider distributions and migratory routes that lead them across the oceans. These habitats include;

- Benthic zones (e.g. the little skate Leuroraja erinacea)

- Coastal waters (e.g. the spiny dogfish Squalus acanthias)

- Cold waters (e.g. the Greenland shark Somniosus microcephalus)

- Deep sea (e.g. the Portuguese dogfish Centroscymnus coelolepis)

- Estuaries (e.g. the smalltooth sawfish Pristis pectinate)

- Lakes (e.g. the bull shark Carcharhinus leucas).

- Mangroves (e.g. the long comb sawfish Pristis zijsron)

- Open sea (e.g. pelagic sting ray Pteroplatytrygon violacea)

- Reefs (e.g. the blacktip reef shark Carcharhinus melanopterus)

- Rivers (e.g. the ocellate river stingray Potamotrygon motor)

- Tropical waters (e.g. the reef manta ray Mobula alfredi)

Depending on local availability, scientists have developed different models. In Europe, Scyliorhinus canicula, or the small-spotted catshark, can be described as a historical Chondrichthyes model in biology (Coolen et al. 2008) (Figure 23.2). Their spatial distribution spans from the Northeast and Eastern Central Atlantic, Norway and the Shetland Islands to Senegal (possibly along the Ivory Coast), as well as throughout the Mediterranean Sea. The IUCN defines the small-spotted catshark as one of the most abundant elasmobranchs in the Northeast Atlantic and Mediterranean Sea (IUCN SSC Shark Specialist Group et al. 2014). As such, the species is assessed as Least Concern.

\subsection{CHONDRICHTHYES LIFE CYCLES}

\subsubsection{Reproductive Strategies}

For all Chondrichthyes, fertilization is internal, and a paired pelvic male organ called claspers deliver sperm inside the female. Additionally to the pelvic claspers, Holocephali have a cephalic clasper (Tozer and Dagit 2004). Female elasmobranchs have been shown to store sperm (Pratt and Carrier 2001). Advantageously for science, Chondrichthyes are the vertebrates with the most diverse reproductive strategies; these include maternal investment, placental viviparity, ovoviviparity or strict lecithotrophic oviparity (yolk-dependent) (Dulvy and Reynolds 1997). These species-specific developmental specializations enable investigations on the evolution of reproductive strategies within a single clade (Mull et al. 2011). Ovoviviparous development, in which eggs hatch internally, is the norm in manta rays, the spiny dogfish, sawfish and whale sharks. The majority of Chondrichthyes species are oviparous (egg-laying): examples include the little skate and the small-spotted catshark. Viviparity or live birth is found in hammerhead sharks, bull sharks and blue sharks. Besides sexual reproduction, asexual parthenogenesis has been observed in captive Chondrichthyes such as the zebrashark (Dudgeon et al. 2017), the hammerhead shark (Chapman et al. 2007) and the sawfish (Fields et al. 2015). Fecundity is as few as 1 to 10 per litter in the electric ray, Torpedo torpedo (Diatta 2000), and as many as 300 per litter for the whale shark, Rhincodon typus (Joung et al. 1996).

Of these reproductive mechanisms, the most conducive to experimental manipulation is oviparity, as it facilitates handling. Importantly, oviparous species act as a steady sample bank for molecular and cellular investigations without needing to sacrifice the mothers. According to Compagno's review (1990) on Chondrichthyes life-history styles, approximately $43 \%$ of Chondrichthyes utilize oviparity, including all Chimaeriformes (chimeras), Heterodontiformes (bullhead sharks), Rajoidae (skates) and Scyliorhinidae (catsharks) (Compagno 1990). Many species can be maintained in captivity and will lay eggs throughout an annual season; embryos at various developmental stages can thus be obtained in the laboratory year-round. Artificial insemination has been reported for two oviparous species, the clearnose skate, Raja eglanteria (Luer et al. 2007), and the cloudy catshark, Scyliorhinus torazame (Motoyasu et al. 2003). Additionally, sperm storage allows wild-caught females to lay eggs for several months (Scyliorhinus canicula, Figure 23.2) without requiring males or captive mating events.

\subsubsection{Chondrichthyes SpeCies IN Developmental Bıology}

Compared to other model species in genetics and development (such as C. elegans or Drosophila), the slow development of Chondrichthyes can be an advantage, as it confers a better spatial and temporal resolution. The choice of a Chondrichthyes model for developmental biology warrants knowledge on the species lifecycle; fecundity, sexual maturity and longevity. Estimated longevity can be as short as ten years for sharpnose sharks, Rhizoprionodon spp. (Cailliet et al. 2001), and as long as 272 years for Greenland sharks (Figure 23.2), Somniosus microcephalus (Nielsen et al. 2016).

A common Chondrichthyes shark model is the oviparous $S$. canicula. Detailed information on the small-spotted catshark such as maturity, fecundity and occurrence is described by Capapé (2008). This species deposits egg-cases 
protected by a horny capsule with long tendrils (Figure 23.2). Embryos, juveniles and adults (Figure 23.2) can be kept in lab facilities. Such is the case at the Station Biologique de Roscoff or at the Observatoire Océanologique de Banyulsde-mer in France.

A Chondrichthyes skate model that is recurrent in developmental biology is the oviparous Leucoraja erinacea, or little skate (see details concerning the suitability of this animal as a lab model in Clifton et al. 2005). Little skates can be maintained in tanks, and egg-carrying females can be identified by palpation. Eggs are produced in pairs at intervals of about seven days, and hatching requires about six months at $15^{\circ} \mathrm{C}$. Refrigerator temperatures can be used to hold embryonic development in stasis. Furthermore, the slow development of Leucoraja erinacea allows removal and in vitro culture of embryonic cells as well as transplantation of modified cells back into the embryo (Mattingly et al. 2004). Thanks to the reduced metabolic rates (ion transport and oxygen consumption) associated with cold-water habitats, the little skate exhibits an increased stability of cells, tissues and cellular macromolecules, including nucleic acids (Clifton et al. 2005).
Most holocephalans are found in the deep waters of the continental shelf and slope and as a result are unlikely candidates for captivity/lab use. The spotted ratfish (Hydrolagus colliei) is one notable exception occurring in near-shore waters (Tozer and Dagit 2004).

The small-spotted catshark and little skate are examples of how Chondrichthyes offer new perspectives for comparative studies of vertebrate development relative to the more traditional zebrafish, Xenopus, avian and mammalian developmental models. Table 23.1 compiles the existing papers on the development of specific Chondrichthyes species.

\subsection{CHONDRICHTHYES EMBRYOGENESIS}

\subsubsection{Early Embryogenesis and Gastrulation}

The main steps of early embryogenesis (ovum to gastrulation) of the elasmobranch embryo are documented for several oviparous species (see Table 23.1), and the following data are based on Balfour and Ballard's descriptions (Balfour 1878; Ballard et al. 1993). As in avian eggs, the cytoplasm

\section{TABLE 23.1}

\section{Compilation of papers that describe a Chondrichthyes' embryogenesis (Conservation status of said species is detailed as reported by the IUCN Red List Status).}

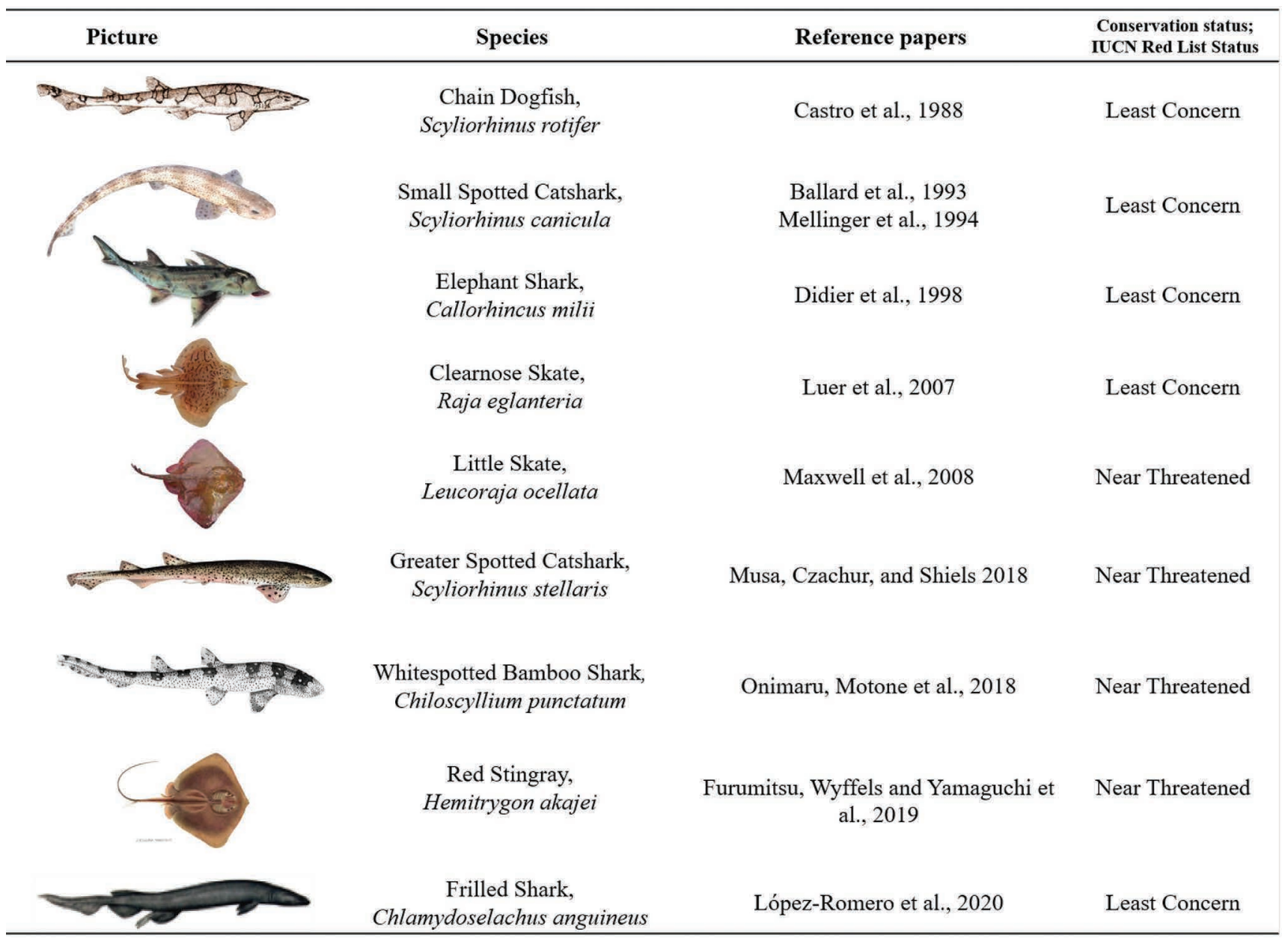


(a)

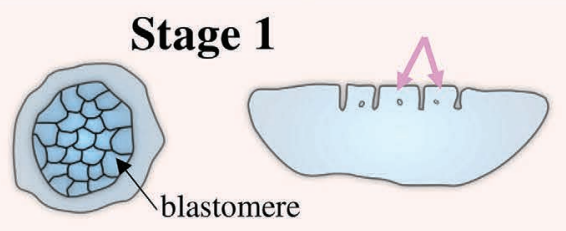

Stage 2
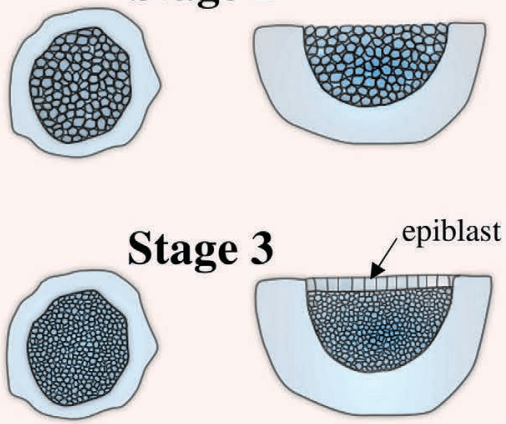

(b)

From stage 4 to 7
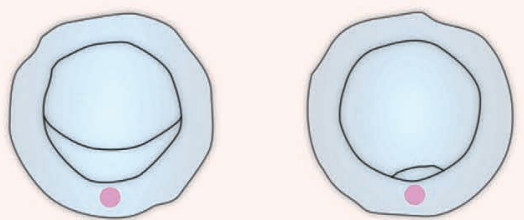

From stage 8 to 10

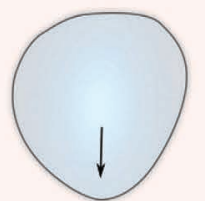

unidirectional spread

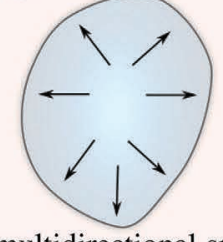

multidirectional spread/ epiboly

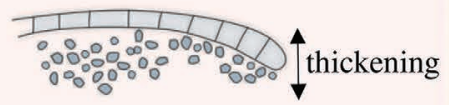

(c)

\section{Stage 11}

(a)
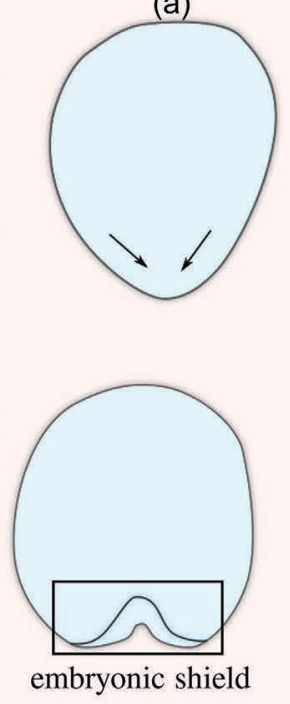

Stage 12

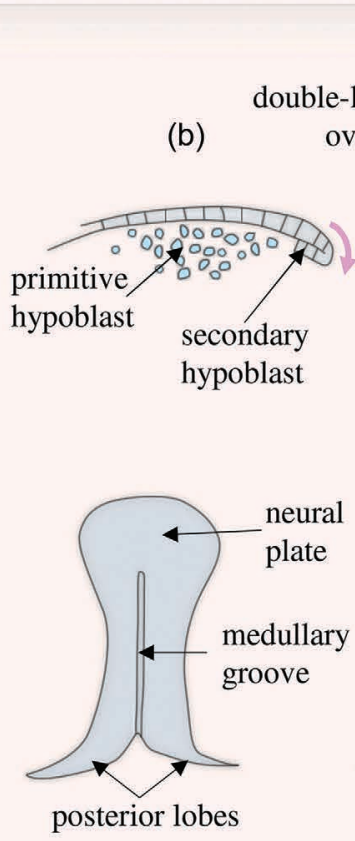

Stage 14

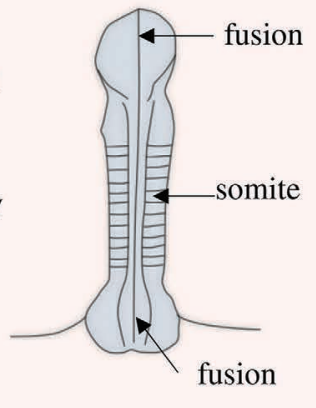

Stage 17

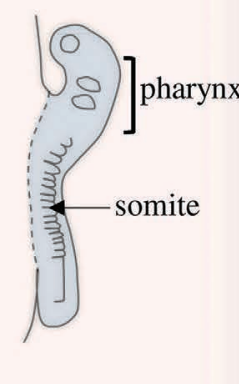

Stage 18

FIGURE 23.3 Early steps of catshark embryogenesis. (a) From stages 1 to 3. Right drawings: dorsal views of the embryo. Left drawings: cross-sections of the corresponding embryos. Pink arrows point to cells of the syncytial blastodisc. (b) From stages 4 to 10 . Pink dots indicate the position of the posterior end of the embryo/blastodisc. Bottom drawing represents a cross-section of the posterior end of the embryo at stage 10. (c) Stages 11 to 18. (a) dorsal view of the embryo at stage 11. Arrows represent cells converging to the midline at the posterior end. (b, c) cross-sections of the embryo at the posterior end (over stage 11). In (b) the pink arrow represents mesendodermal cells involuting above the archenteron. (c) the horizontal pink arrow illustrates cell movements from the involuting mesendoderm. The vertical arrow illustrates the movement of single cells internalized from the upper layer. (Adapted from Balfour (1878), Vandebroek (1936), Ballard et al. (1993). Artwork: David Wahnoun, DigitalMarine.) 
comprises large amounts of yolk, making segmentation possible in only a small portion of the telolecithal egg cell. These first cleavages start within the oviduct with the particularity of being incomplete. Cell membranes of the first blastomeres do not close up at their bases so that the cytoplasms and the underlying yolk are continuous and form a syncytial blastodisc (stage 1, Figure 23.3A). Around the 100-cell stage, the blastodisc is not syncytial anymore, and the loosely arranged blastomeres exhibit a spherical morphology (stage 2, Figure 23.3A). Later on, the density of inner blastomeres increases, and they are covered by an epithelium made of columnar cells, the epiblast (stage 3, Figure 23.3A). Dorsal views of the blastodisc will later display a crescent-like structure at the posterior end that will finally disappear (from stages 4 to 7 , Figure 23.3B). From stages 8 to 10 , the round blastodisc shifts to an oval shape due to a unidirectional posterior spread (Figure 23.3B). As epiboly proceeds, the spreading of the blastodisc becomes multidirectional, and a thickening starts to be observed at the posterior end. This cellular densification in the posterior area of the blastoderm tends to intensify at stage 10 (Figure 23.3B, cross-section).

An important feature of the stage 11 embryo is the folding of the epithelial upper layer over the yolk, generating a double-layered overhang (Figure 23.3C, a, b and c). The space created between this overhang and the yolk corresponds to the future archenteron of the embryo. Gastrulation properly starts at this stage, with the lower layer of the overhang representing the mesendodermal cells involuting above the archenteron (Figure 23.3C, b). This forming mesendodermal layer can be referred to as a secondary hypoblast, while the mass of inner blastomeres is called the primitive hypoblast (Ballard et al. 1993, Figure 23.3C, b). Several studies described cell movements accompanying mesendoderm and mesoderm formation during gastrulation. Cell tracking experiments showed that labeled cells within the upper layer of the overhang at the very beginning of stage 11 are later displaced onward within the involuting mesendoderm layer (Godard et al. 2014, Figure 23.3C, c). Similar experimental approaches revealed that single cells can be internalized from the upper layer of the blastoderm to take part in mesoderm formation (Godard et al. 2014, Figure 23.3C, c). On the other hand, Balfour (1878) observed that epithelial cells at the tip of the involuting mesendoderm undergo a morphological "transition", acquiring the shape of the inner rounded blastomeres (Figure 23.3C, c). Similar cell shape changes in this area have also been reported by Coolen et al. (2007). These observations suggest that epithelial cells both from the upper layer (epiblast) and from the tip of the involuting mesendoderm undergo an epithelial to mesenchymal transition (EMT) during gastrulation. In situ hybridization experiments performed with the mesoderm marker Brachyury at this stage in catshark embryos suggest other types of movements. In addition to being expressed at the site of the involuting mesendoderm, its expression pattern also describes a thin ring all around the blastoderm, which suggests that cells from the margin are converging to the midline at the posterior end of the embryo (Sauka-Spengler et al. 2003)
(Figure 23.3C, a). The convergence of cells from the periphery of the blastoderm to the posterior end of the midline has been initially reported by Vandebroek (1936). In the future, development of live imaging approaches on elasmobranch embryos would definitively help to shed light on the spatial and temporal behaviors of their cells during gastrulation.

\subsubsection{From Axis Formation to Pharynx Segmentation}

At stage 12, the posterior end of the blastoderm exhibits a V-shaped structure referred to as the embryonic shield (Figure 23.3C). A slight depression is observed in the middle of the embryonic shield. It will give rise, by extension from posterior to anterior, to the medullary groove, stating the position of the embryonic axis (Figure 23.3C, stage 14). As the embryo increases in length, the anterior part will enlarge (neural plate, Figure 23.3C, stage 14) and rise to form the neural/medullary folds. In the posterior region, the two arms of the embryonic shield (posterior lobes, Figure 23.3C, stage 14) will progressively shrink to fuse and enclose the neural tube and the archenteric cavity (Figure 23.3C, stage 17). Similar fusion of the neural folds is observed in the anterior part (Figure 23.3c, stage 17). Several pairs of somites are formed during the process of neural tube closure (Figure 23.3C, stage 17). While the trunk pursues its segmentation through the formation of additional somite pairs, the pharynx area undergoes metamerization, too; several branchial clefts will appear (Figure 23.3C, stage 18).

\subsection{CHONDRICHTHYES ANATOMY AND SENSORY BIOLOGY}

\subsubsection{External Features}

In this section, typical Chondrichthyes body plans will be proposed for Selachimorpha, Batoids and Holocephalans, and general external features will be briefly discussed. For a more detailed account of Chondrichthyes anatomy, The Dissection of Vertebrates, Second Edition by Gerardo De Iuliis and Dino Pulerà is highly informative (2019).

All Chondrichthyes breathe through five to seven pairs of gills, depending on the species. As a general rule, pelagic (open sea) species have to keep swimming to ensure that oxygenated water is moving through their gills. Demersal species, which live in the water column near the sea floor, will actively pump water in through their spiracles and out through their gills (Salazar 2018). Spiracles are respiratory openings into the pharynx. For sharks, the gills are located on the sides of the body, while the gills are ventral for batoids (De Iuliis and Pulerà 2019). Elasmobranch gill structure and function are described by Wegner (2015). Holocephalans have a single gill opening, on each side, located just anterior to the base of the pectoral fin.

Most sharks, sawfish and chimeras have a heterocercal tail (with unequal upper and lower lobes). This particular 
structure has been showed to aid in locomotion (Wilga and Lauder 2002). For skates, however, tails range from a thick tail extending from the body to a whip to almost no tail. Stingrays (batoids) possess a venomous stinger located in the mid-area of the tail. This particularity has brought on studies on the chemistry of their venom (da Silva et al. 2015). In most holocephalans, the first dorsal fin is preceded by a venomous spine that can inflict a serious wound (Halstead and Bunker 1952).

Chondrichthyes have tough skin covered with dermal teeth, also called placoid scales (or dermal denticles). The dermal skeleton is the most ancestral mineralized skeleton (see Gillis et al. 2017 for more information) and dermal denticles in the skin of elasmobranchs as well as teeth in the head of all jawed vertebrates are remnants of this structure (Gillis et al. 2017). Torpediniformes (electric rays) form an exception, as they have a thick and flabby body, with smooth and loose skin. Notably, Holocephali lose their dermal denticles as adults to keep only those on the clasping organ seen on the caudal ventral surface of the male (Salazar 2018). Denticles usually provide protection and, in most cases, streamlining (Salazar 2018). On another level, denticles make the skin of the catshark and the common stingray a highly sought-after product for luxury lining and leatherwork. Called shagreen (or galuchat in French), the use of this skin to wrap travel cases and manufacture holders is mentioned by Buffon as early as 1789 in the second volume of Histoire naturelle des poissons (Buffon 1789).

In some shark species, such as the lantern shark, denticles even house bioluminescent bacteria that aid in intraspecific communication (Claes et al. 2015). In 2018, shark denticles were discovered to be laid out according to a Turing-like developmental mechanism explained by a reaction-diffusion system (Cooper et al. 2018).

As aforementioned, bioluminescence and biofluorescence can occur in certain Chondrichthyes species. Bioluminescence is the ability of living beings to radiate light on their own or with the help of certain symbiotes (e.g. bacteria). Biofluorescence is the process in which ambient light is absorbed via fluorescent compounds and reemitted at longer, lower-energy wavelengths. Examples of bioluminescent sharks include Etmopterus spinax (velvet belly lantern shark) (Claes et al. 2010), Euprotomicrus bispinatus (dwarf pelagic shark) (Hubbs et al. 1967) or Squaliolus aliae (smalleye pygmy shark) (Claes et al. 2012). They display light-emitting organs (photophores) on their undersides that form species-specific patterns over the flanks and abdomen. The ventral photophores are considered to participate in counter-illumination, a method of camouflage that uses light production to match background brightness and wavelength (Sparks et al. 2014). The bioluminescent flank markings may play a role in intraspecific communication (Gruber et al. 2016). The roles of biofluorescence are more elusive. The Urotrygonidae (American round stingrays), Orectolobidae (wobbegongs) and Scyliorhinidae (catsharks) families include fluorescent species. As these families are distantly related, biofluorescence is thought to have evolved at least three times in elasmobranchs (Gruber et al. 2016). The swell shark (Cephaloscyllium ventriosum), the chain catshark (Scyliorhinus rotifer) and round stingray (Urobatis jamaicensis) are known to exhibit bright green fluorescence (Sparks et al. 2014). The family of small molecules behind marine biofluorescence reviewed in Park et al. (2019) have been hypothesized to play a role in central nervous system signaling, resilience to microbial infections and photoprotection.

\subsubsection{InTERNAL ANATOMY}

This section is a selection of specific traits of Chondrichthyes anatomy deemed important to mention. As the etymology of the term Chondrichthyes indicates, they possess a cartilaginous skeleton.

For Selachii, the mouth is ventrally located. The upper and lower jaws are lined by multiple rows of serrated, triangular and pointed teeth that continuously grow and shed (De Iuliis and Pulerà 2019). Instead, batoids possess flattened plates for crushing bottom-dwelling prey (De Iuliis and Pulerà 2019). Gynandric heterodonty (sexual dimorphism in teeth) is very common in elasmobranchs, and Berio et al. (2020) described the intraspecific diversity of tooth morphology in the large-spotted catshark and revealed some of the ontogenic cues driving this sexual dimorphism. Holocephalans possess three pairs of tooth plates, two in the upper jaw and a single pair in the lower jaw (Tozer and Dagit 2004). Sawfish (Rhinopristiformes, Batoids, Elasmobranch) are characterized by a long, narrow and flattened rostrum (nose extension) lined with transversal teeth. This feature can also be found in sawsharks (Pristiophoriformes, Selachii, Elasmobranch).

Chondrichthyes have no swim bladders. Buoyancy is rather controlled with a large oil-filled liver, which reduces their specific density. An interesting feature of sharks is the valvular intestine, which bears a spiral valve, a corkscrew-shaped lower portion of the intestine that increases its effective length (De Iuliis and Pulerà 2019). Remarkably, chimeariformes lack stomachs (Salazar 2018).

Unlike mammals, Chondrichthyes do not have bone marrow, and red blood cells are produced in the spleen and the epigonal organ. The epigonal organ is a special tissue around the gonads that is only found in certain cartilaginous fish and thought to play a role in the immune system. Red blood cells are also produced in the Leydig's organ (nested along the top and bottom of the esophagus), which is also considered part of the immune system (Mattisson and Faänge 1982). The subclass Holocephali lacks both the Leydig's and epigonal organs.

Elasmobranch kidneys deserve a special mention, and the little skate and spotted catshark have been of particular interest for the study of kidney development. The functional unit of the kidney is the nephron, and the process of nephron formation is termed nephrogenesis. In mammals, nephrogenesis comes to a stop shortly after birth. This means nephron endowment is definitive in mammals at birth. Some elasmobranchs have been found to continually 
form nephrons even after embryonic development. Using kidney histological sections from a spotted catshark juvenile, Hentschel (1991) described nephrogenesis with similar morphological steps as found during mammalian nephrogenesis (Hentschel 1991). This unique capacity is a promising research area to better understand the orchestrating factors behind kidney morphogenesis.

Elasmobranch species possess a rectal (or salt) gland. This epithelial organ is located in the distal intestine and empties into the cloaca. It is composed of many tubules that serve a single function: the secretion of hypertonic $\mathrm{NaCl}$ solution (Forrest 2016). Initially discovered by Wendell Burger and Walter Hess (1960), this organ can be cannulated and perfused, and chloride secretion can be measured. As highlighted by Forrest (2016), this organ has helped in understanding the physiology of the mammalian thick ascending limb (TAL), an inaccessible portion of the kidney, which functions to filter sodium $\left(\mathrm{Na}^{+}\right)$, potassium $\left(\mathrm{K}^{+}\right)$ and chloride $\left(\mathrm{Cl}^{-}\right)$.

\subsubsection{Sensory Biology}

Chondrichthyes are gifted with a plethora of senses that are more or less developed depending on the species. The sensory biology of Chondrichthyes can be divided into visual, acoustic, mechanical, chemical, magnetic and electrical detection.

\subsubsection{Photoreception}

Studies that focus on visual function in Chondrichthyes have described differing sensitivities to light and colors (Douglas and Djamgoz 2012). Depending on the ecological niche they occupy, Chondricthyes have evolved different morphological adaptations to optimize photoreception. These include variation in eye size, eye positioning, mobile pupils, elaborate pupillary opercula and reflective retinal media (Walls 1942). The variety of pupil shapes (horizontal, oblique, U-crescent shaped slits) and pupillary opercula is striking. Usually, elasmobranchs benefit from large visual fields - a horizontal arc of up to $360^{\circ}$ (McComb and Kajiura 2008)—while humans have a $210^{\circ}$ horizontal arc. Elasmobranch retinas include both rod cells, which allow perception in dim-light conditions, and cone cells, which allow perception in bright-light conditions, higher acuity and possible color distinction (Jordan et al. 2013). Ecological factors seem to condition the proportion of rods and cones and the spectral sensitivity of cones. For example, species that inhabit the dysphotic and aphotic zone possess fewer to no cones (Collin et al. 2006). Concerning batoids, eyes are usually located dorsally, though lateral eye position can also be observed, and eyes can even be vestigial in some electric rays. Some batoids (skates, rays and guitarfish) exhibit several spectrally specific cone pigments that would entail the ability for color discrimination (Hart et al. 2004, Theiss et al. 2007). In 2016, the giant guitarfish (Rhynchobatus djiddensis) was discovered to possess the ability to retract its eyes, possibly as a means of protection during predation (Tomita et al. 2016).

\subsubsection{Audition}

Myrberg recounts the history of investigations concerning the hearing abilities of sharks in his Acoustical Biological of Elasmobranch review (2001). For sharks, the highest sensitivity has been demonstrated for low-frequency sounds (40 to $800 \mathrm{~Hz}$ ). Specific sound characteristics attract free-ranging sharks: irregular pulses without sudden increases in intensity and frequencies below $80 \mathrm{~Hz}$. Such characteristics are evocative of wounded or struggling prey (Myrberg 2001). This is an auditory explanation behind the role that sharks play in regulating the health of ocean populations. Recently, Parmentier et al. (2020) described the hearing abilities of the catshark, Scyliorhinus canicula, from early embryos to juveniles. Stage 31 embryos were able to detect sounds from 100 to $300 \mathrm{~Hz}$, while juveniles were able to detect sounds from 100 to $600 \mathrm{~Hz}$. As hearing development continues in the catshark, only the frequency range appears to widen, as sensitivity and thresholds were not found to improve with development (Parmentier et al. 2020). This last paper contains references to other studies on Chondrichthyes hearing abilities, namely hearing thresholds, frequency range and ear morphology.

\subsubsection{Mechanosensory System}

The mechanosensory systems of elasmobranchs include different tactile sense organs; receptor types and distribution depend on the species (Maruska 2001; Jordan 2008). These systems include lateral line canals, neuromasts and vesicules of Savi (types of sensory hair cells and their supporting cells) and spiracular organs. The lateral line marks the lateral line canals, which contain sensory nerve endings and open to the surface through tiny pores (De Iuliis and Pulerà 2019). These tactile sense organs respond to pressure variations induced by the velocity or acceleration of water flow. The electrosensory and lateral line systems of sawfish extend out along the rostrum. This allows them to sense and manipulate prey (Wueringer et al. 2011).

\subsubsection{Chemoreception}

Sensitivity to chemical signals through taste, chemical sense and olfaction constitutes another sense for Chondrichthyes. The underlying organs behind these functions include olfactory sacs (for olfaction) and taste papillae (gustation). Sharks have been found to locate potential food using the difference in bilateral odor arrival times (Gardiner and Atema 2010). Pharyngeal denticles and taste papillae possess receptors used for gustation. The morphological adaptations that are pharyngeal denticles could help sharks catch and direct food items and prevent injury of the mouth lining during food manipulation and consumption (Atkinson et al. 2016). Both dermal and oral denticles possess species-specific microstructural morphology that can be applied as a taxonomical tool (Bs et al. 2019). During odor source localization, combinatory signals will help locate potential prey. Gardiner and Atema (2007) looked into the contribution of different senses (olfaction, mechanoreception and vision) to odor perception in the smooth dogfish Mustelus canis. Interestingly, 
they found that the lateral line is required to locate odor sources (Gardiner and Atema 2007).

\subsubsection{Magnetoreception}

Fascinatingly, elasmobranchs have been observed to swim in straight lines for extended periods of time in a highly oriented manner and to navigate in relation to magnetic fields. These observations are true for tiger sharks (Galeocerdo cuvier; Holland et al. 1999), blue sharks (Prionace glauca; Carey et al. 1990) and scalloped hammerhead sharks (Sphyrna lewini; Klimley 1993). Meyer et al. (2005) showed experimentally that sharks can detect variations in the geomagnetic field. They performed condition experiments on captive sharks to determine how they detect magnetic fields and to measure detection thresholds. The anatomical modules underlying magnetoreception could be mediated directly via a magnetite-based sensory system or indirectly via the electrosensory system (Sundström et al. 2001). Indeed, the exact cells, molecules and receptors behind magnetoreception in elasmobranches remain unknown.

\subsubsection{Electroreception}

Electroreception is important in many Chondrichthyes. In 1678, Stefano Lorenzini first described pores dispersed on a shark's head without identifying their sensory role. It was only in the 1960s that their function began to be elucidated and identified as a modified part of the lateral line system. Named after Stefano Lorenzini, the ampullae of Lorenzini form a network of jelly-filled pores that act as sensing organs. These pores are connected to sensory cells by gel-filled canals and are highly sensitive to low-frequency electrical stimuli produced by both non-biological and biological sources. Ampullae of Lorenzini are mostly described in Chondrichthyes; however, they are also found in Chondrostei. Chondrostei are Actinopterygii in which the cartilaginous skeleton is a derived feature. They include reedfish, sturgeon and bichir. On the other hand, rays possess an electric organ that originates from modified nerve or muscle tissue. The electric field created by this organ is used for navigation, communication, mating (Feulner et al. 2009), defense and the incapacitation of prey.

Jordan et al. (2013) extensively reviewed both the current knowledge on elasmobranch sensory systems and the way in which these sensory systems could inspire methods for bycatch reduction. The following references will allow a deeper look into the sensory system anatomies of sharks (De Iuliis and Pulerà 2019), batoids (Bedore et al. 2014; Wueringer et al. 2011) and holocephalans (Tozer and Dagit 2004; Lisney 2010).

\subsection{GENOMIC DATA}

\subsubsection{Genomes and Transcriptomes}

With millions of species on earth, very few genomes or transcriptomes are in fact assembled, annotated and published. However, the availability of this data (genomes, transcriptomes or protein sequences) greatly accelerates studies on phylogeny (Li et al. 2012; Straube et al. 2015), species diversity and population structure (Boussarie et al. 2018), conservation (Corlett 2017), evolutionary history (Inoue et al. 2010; Renz et al. 2013) or human health research. More generally, studies that encompass diverse animal models to compare sequences have been critical for deciphering fundamental physiological mechanisms and conserved gene and protein functions. Another approach is to compare closely related genomes to identify divergent sequences that may underlie unique phenotypes (Stedman et al. 2004). Several studies have shown that non-coding sequences are more comparable between the genomes of humans and cartilaginous fish than between those of humans and zebrafish (Venkatesh et al. 2006; Lee et al. 2011). Both the slower molecular clock of cartilaginous fish relative to teleosts' (Venkatesh et al. 2014; Renz et al. 2013; Martin et al. 1992), as well as the extra whole-genome duplication specific of teleosts (Glasauer and Neuhauss 2014), can explain the comparability of human and Chondrichthyes genomes.

In 2013, a tissue-specific transcriptome was generated from the heart tissue of the great white shark (Carcharodon carcharias) (Richards et al. 2013). This represented the first transcriptome of any tissue for this species. Strikingly, this transcriptome revealed that the percentage of annotated transcripts involved in metabolic processes was more similar between the white shark and humans than between the white shark and a teleost (Richards et al. 2013). This finding is consistent with those of Venkatesh et al. (2006) who found genomic non-coding elements and the relative position of genes to be more similar between the elephant shark and humans than between the elephant shark and a teleost. In 2014, the first large-scale comparative transcriptomic survey of multiple cartilaginous fish tissues was analyzed: the pancreas, brain and liver of the lesser spotted catshark, Scyliorhinus canicula (Mulley et al. 2014). This study contributes to deciphering the molecular-level functions of pancreatic metabolic processes of Chondrichthyes. Uncommonly, Chondrichthyes possess the ability to both maintain stable blood glucose levels and tolerate extensive periods of hypoglycemia (Mulley et al. 2014). A highcoverage whole-genome sequencing project of $S$. canicula is underway (Génoscope, French National Sequencing Center and laboratory of Sylvie Mazan, Observatoire Océanologique de Banyuls sur Mer, France). A collection of catshark expressed sequence tags (ESTs) is also available in Mazan's lab. The first Chondrichthyes whole genome to be sequenced was of the holocephalan Callorhincus milii, published by Venkatesh et al. (2014). The genome size is approximately $1 \mathrm{Gbp}$. The same year, Wyffels et al. sequenced both the nuclear and mitochondrial genomes of the little skate (Leucoraja erinacea). The genome represents $3.42 \mathrm{Gbp}$ across 49 chromosomes. Wyffels et al. (2014) introduced Skatebase (www.skatebase.org), a project for the collection of elasmobranch genomes to complete molecular resources for Chondrichthyes fish. Additionally, to the little skate genome, mitochondrion sequences from the ocellate spot skate (Okamejei kenojei) and thorny skate (Amblyoraja 
radiata) as well as transcriptomes from the spotted catshark and elephant shark can be found. Skatebase also regroups the Chondrichthyes sequence data found in NCBI databases, UniProtKB and the Protein Data Bank (PDB) of Leucoraja erinacea, Callorhinchus milii and Scyliorhinus canicula. Skateblast, hosted on Skatebase, provides a Chondrichthyesspecific blast platform with the previously mentioned data. Genomic contigs and features are available for download. In 2017, the draft sequencing and assembly of the genome of the whale shark, Rhicodon typus, was published by Read et al. (2017). The whale shark genome represents $3.44 \mathrm{Gbp}$. In 2018, the brown-banded bamboo shark, Chiloscyllium punctatum, and the cloudy catshark, Scyliorhinus torazame, de novo whole genomes as well as an improved assembly of the whale shark genome were presented by Hara et al. (2018). The genome size of the brownbanded bamboo shark is 4.7 Gbp and the cloudy catshark 6.7 Gbp. In 2018, both the zebra bull-head shark (Onimaru et al. 2018) and ocellate spot skate (Tanegashima et al. 2018) transcriptomes were published. Lastly, in 2019, the white-shark (Carcharodon carcharias) genome was published by Marra et al. (2019) with a size of $4.63 \mathrm{Gpb}$. Figure 23.4 represents a timeline of the Chondrichthyes genomes and transcriptomes with reference publications. Further information concerning gene repertoires, genome size variation, ploidy level, sequence composition can be found in a recent review dedicated to elasmobranch genomics (Kuraku 2021).

\subsubsection{Gene Family Studies}

A gene family is a set of several similar genes formed by duplication of a single original gene and generally with similar biochemical functions. The Hox family are well-known genes which act as major regulators of animal development.
Developmental expression profiling and transcriptome analysis first described a lack of expression of the 11 HoxC genes in S. canicula and L. erinacea (Oulion et al. 2010, 2011; King et al. 2011). This finding was initially attributed to a genomic deletion of the entire HoxC cluster in these taxa (Oulion et al. 2010; King et al. 2011). A higher coverage sequencing has revealed that HoxC genes might in fact exist, but their genomic distributions and the elevated evolutionary rate of their sequences have rendered analysis difficult (Hara et al. 2018). Indeed, examination of several elasmobranch genome scaffolds comprising the presumed HoxC genes indicated that the cluster is far from as compact as the clusters of other vertebrate Hox genes (Hara et al. 2018). This type of situation highlights the importance of the quality of genomic databases that depends on sequencing depth and coverage. Furthermore, Chondrichthyes genomic databases can give insight on the evolution of vertebrate gene repertoires such as the gonadotropin-releasing hormone $(\mathrm{GnRH})$ (Gaillard et al. 2018), Fox genes (Wotton et al. 2008) or detoxification gene modules (Fonseca et al. 2019).

\subsection{TOOLS FOR MOLECULAR AND CELLULAR ANALYSES}

\subsubsection{Cell Lines}

Cell lines are transformed cell populations with the ability to divide indefinitely. They are powerful tools in understanding physiological, pathophysiological and differentiation processes of specific cells under controlled environmental conditions. Until 2007, no Chondrichthyes cell line existed. Currently, two cell lines exist: the SAE cell line derived from Squalus acanthias, and LEE-1, derived from an early embryo of Leucoraja erinacea. The SAE cell line was the

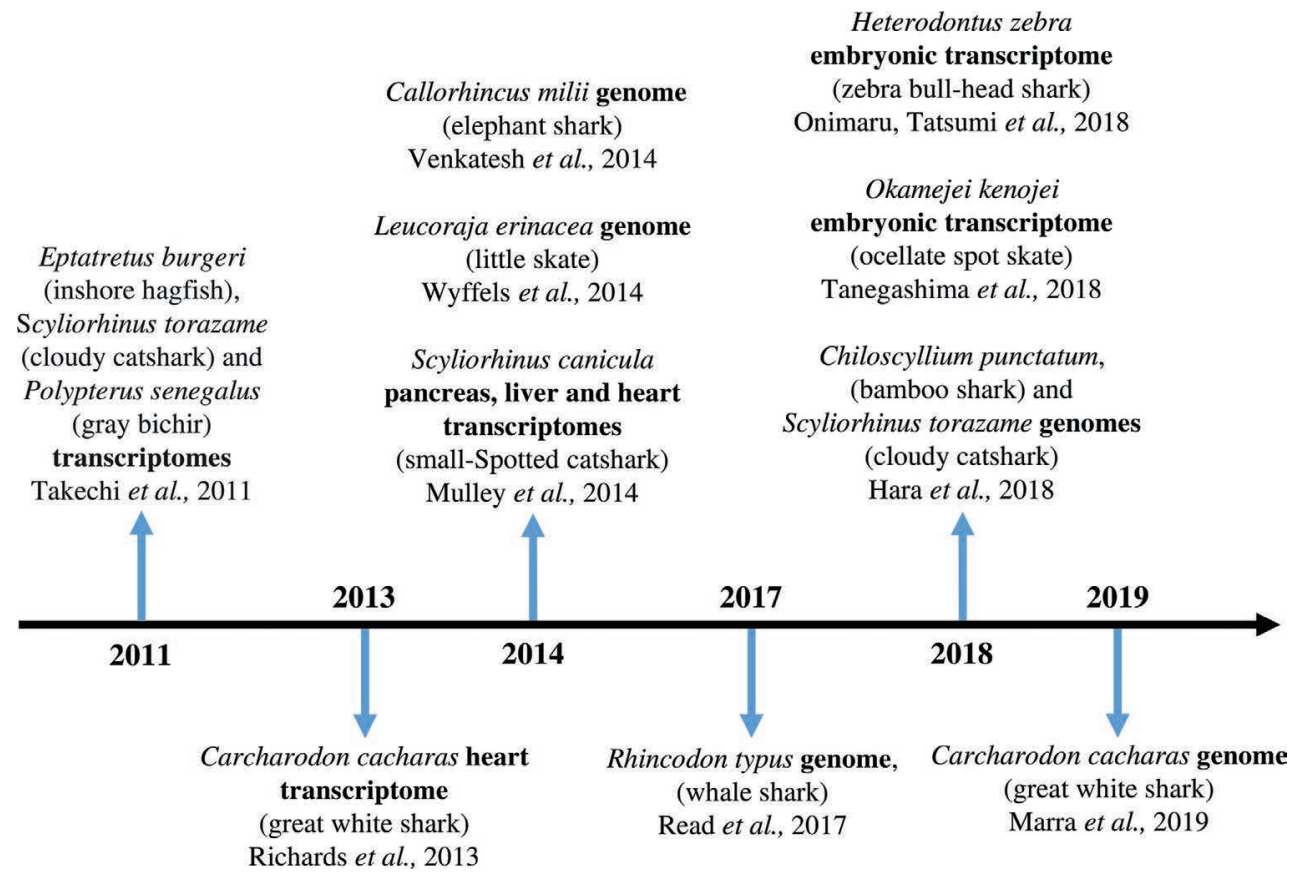

FIGURE 23.4 Timeline showing Chondrichthyes genome and transcriptome publications. 
first multi-passage continuously proliferating cell line of a cartilaginous fish. Derived from Squalus acanthias mesenchymal cells, the primary culture was dispensed into several collagen-coated wells of a 48-well plate. This culture was maintained in a medium modified for fish species and supplemented with cell-type specific hormones, other proteins and sera and plated on a collagen substrate (Parton et al. 2007). SAE cells have been continuously proliferating for three years. For the LEE-1 cell line, isolation and culture were initiated with a stage 28 little skate embryo (Hwang et al. 2008). Similarly to the SAE cell line, cultures for the LEE-1 line were dispensed into collagen-coated wells of a 24-well plate with a basal nutrient medium supplemented with antibiotics and cell-type specific hormones, other proteins and sera.

\subsubsection{Descriptive and Functional Approaches}

Tools for molecular and cellular analyses have historically been developed with classical models (e.g., Xenopus, Drosophila or the mouse). The emergence of novel animal models has brought challenges in adapting these tools to varying frameworks. The value of Chondrichthyes models in experimental biology, which depends on the success of descriptive and functional approaches, is illustrated in Table 23.2. These approaches generate anatomical and structural data as well as valuable information on molecular mechanisms. The proposed methods can help deepen our understanding of the dynamics of developmental gene patterns, cell fate during morphogenesis, metabolic functions or the mechanisms of tissue regeneration.

\section{TABLE 23.2}

\section{Compiled descriptive and functional approaches successfully performed on Chondrichthyes species with reference} papers for protocol examples. The list of reference papers is not exhaustive

\begin{tabular}{|c|c|c|c|}
\hline $\begin{array}{l}\text { Descriptive approaches: } \\
\text { Technique name }\end{array}$ & Papers for reference & $\begin{array}{l}\text { Functional } \\
\text { approaches: } \\
\text { Technique name }\end{array}$ & Papers for reference \\
\hline $\begin{array}{l}\text { Alizarin red and } \\
\text { Alcian blue clear staining }\end{array}$ & $\begin{array}{l}\text { Eames BF et al. } 2007 \text { J Anat } \\
\text { O'Shaughnessy KL et al. } 2015 \text { Nat Commun } \\
\text { Onimaru K et al } 2015 \text { eLife } \\
\text { Cooper RL et al. } 2017 \text { Evol Dev } \\
\text { Gillis JA et al. } 2017 \text { PNAS }\end{array}$ & Beads implantations & O'Shaughnessy KL et al. 2015 Nat Commun \\
\hline $\begin{array}{l}\text { Cryostat sections } \\
\text { Cryo-scanning electron } \\
\text { microscopy }\end{array}$ & $\begin{array}{l}\text { Sauka-Spengler T et al. } 2001 \text { Dev Genes } \\
\text { EvolDean MN et al., } 2008 \text { Micro Today }\end{array}$ & BrdU injection & $\begin{array}{l}\text { Vandenplas S et al. } 2016 \text { Dev Biol Lagadec } \\
\text { R et al. } 2018 \text { Sci Rep }\end{array}$ \\
\hline $\begin{array}{l}\text { Electron microscopy (with } \\
\text { sample coating) }\end{array}$ & Compagnucci C et al., 2013 Dev Biol & Cell lines & $\begin{array}{l}\text { Parton A et al., } 2007 \text { Comp Biochem Physiol } \\
\text { C Toxicol Pharmacol } \\
\text { Hwang J-H et al., 2008 Comp Biochem } \\
\text { Physiol C Toxicol Pharmacol }\end{array}$ \\
\hline $\begin{array}{l}\text { In situ hybridization on } \\
\text { sections }\end{array}$ & $\begin{array}{l}\text { O’Neill P et al., } 2007 \text { Dev Biol_Jung H et al., } \\
2018 \text { Cell }\end{array}$ & $\begin{array}{l}\text { DiI Injection or } \\
\text { DiI Cell labelling }\end{array}$ & $\begin{array}{l}\text { Godard BG et al. } 2014 \text { Biol Open illis JA et } \\
\text { al. } 2017 \text { PNAS }\end{array}$ \\
\hline $\begin{array}{l}\text { Large-scale scan with } \\
\text { high-resolution X-ray } \\
\text { computed tomography }\end{array}$ & Coates MI et al., 2018 Proc Royal Soc B & EdU injection & Gillis JA et al., 2016 Dev \\
\hline $\begin{array}{l}\text { Micro-computerised } \\
\text { tomography (MicroCT) }\end{array}$ & $\begin{array}{l}\text { Dean MN et al. } 2009 \text { J Anat Rasch LJ et al., } 2016 \\
\text { Dev Bio Cooper RL et al., } 2017 \text { Evol Dev }\end{array}$ & Embryo cultures & $\begin{array}{l}\text { Onimaru K et al. } 2015 \text { eLife } \\
\text { Onimaru K et al 2018. Dev Dyn }\end{array}$ \\
\hline Shark MRI & $\begin{array}{l}\text { 3D Shark T1-Weighted MRI (Biomedical } \\
\text { Research Imaging Center of the UNC } \\
\text { school of Medicine) }\end{array}$ & $\begin{array}{l}\text { Extracellular } \\
\text { recordings } \\
\text { of the spinal cord }\end{array}$ & Jung H et al., 2018 Cell \\
\hline $\begin{array}{l}\text { Paraffin embedding and } \\
\text { sectioning for } \\
\text { immunochemistry, } \\
\text { histological coloration, } \\
\text { in situ hybridization }\end{array}$ & Lagadec R et al., 2015 Nat Commun & $\begin{array}{l}\text { In ovo / Ex ovo } \\
\text { drug treatment }\end{array}$ & $\begin{array}{l}\text { Godard BG et al. } 2014 \text { Biol Open [1] } \\
\text { Lagadec R et al. } 2015 \text { Nat Commun [1] } \\
\text { Onimaru K et al., } 2015 \text { eLife [2] } \\
\text { O’Shaughnessy KL et al., 2015 Nat Commun [3] } \\
\text { Gillis JA et al., 2016 Dev [4] } \\
\text { Cooper RL et al., } 2017 \text { Evol Dev [5] Jung H } \\
\text { et al., } 2018 \text { Cell [6] }\end{array}$ \\
\hline Retrograde labelling & Jung H et al., 2018 Cell & TUNEL assays & $\begin{array}{l}\text { Debiais-Thibaud M et al., } 2015 \text { BMC Evol } \\
\text { Biol }\end{array}$ \\
\hline Vibratome sections & Jung H et al., 2018 Cell & & \\
\hline $\begin{array}{l}\text { WISH (whole mount } \\
\text { in situ hybridization) }\end{array}$ & Sauka-Spengler T et al. 2003 Dev Biol & & \\
\hline
\end{tabular}

[1] Nodal inhibitor SB-505124 [2] Retinoic acid [3] Cyclopamine; 11-KT, SHH-N protein and flutamide [4] Cyclopamine [5] FGF-receptor inhibitor SU5402 [6] Electroporation of hox expression constructs. 


\subsection{CHALLENGING QUESTIONS}

\subsubsection{Endogenous ChOndR/Chthyes Molecules for Biomedical Applications}

\subsubsection{Molecules Displaying Antibiotic Activity}

The well-known squalamine is a cationic steroid isolated from stomach extracts of the spiny dogfish Squalus acanthias. It has been demonstrated to display antibacterial activity against Gram-negative and Gram-positive bacteria (Moore et al. 1993). Interestingly, the same study reported that squalamine induced osmotic lysis of Paramecium caudatum and had activity against Candida albicans, indicating that this shark molecule also holds antiprotozoal and fungicidal properties. As the research on squalamine progressed, it revealed that its chemical features extend beyond the antimicrobial field. This aspect will be presented in the following paragraph.

Microorganisms themselves can produce natural antimicrobial agents, meaning that bacterial symbionts in general can constitute an additional "tissue" to look for putative antibiotics. One specificity of Chondrichthyes is their considerable resistance to infection even when their skin is profoundly damaged due to events related to their lifestyle (mating, predation) or to anthropogenic activities. This observation strongly suggests that an innate immunity is operating through the mutualistic interactions taking place in the epidermal mucus layer between marine bacteria and shark epidermis. The most recent study that has investigated the property of these probiotic bacteria is the one from Ritchie et al. (2017). They analyzed the entire bacterial community of the epidermal mucus of three ray species (two marine and one freshwater) and of the clearnose skate, Raja eglanteria. They clearly identified particular strains displaying broad-spectrum antibiotic activity and activity against important nosocomial bacteria (Vancomycinresistant Enterococcus [VRE] and Methicillin-resistant $S$. aureus [MRSA]). It goes without saying that interdisciplinary research, in this case intermingling marine microbiology and organism biology, has always sharpened our understanding of immune defense mechanisms. These data on shark epidermis might help medical research in seeking new antimicrobial compounds but also, more generally, in focusing on the preservation of symbiotic bacteria to prevent many types of human diseases and infections. As in Chondrichthyes, these bacteria play a fundamental role in our immunity.

\subsubsection{The High Specificity of Chondrichthyes Antibodies}

The Chondrichthyes adaptative immune system has many shared features with other gnathostomes (Flajnik 2018), except for their particular antibodies. These immunoglobulin (Ig)-like molecules, also called immunoglobulin new antigen receptors (IgNARs), are made of two heavy chains, lack light chains and bear a single variable region domain (V-NARs). In other words, they have one antigen recognition site instead of two, as is the case in the large majority of jawed vertebrate antibodies. Discovered in the 1990s (Greenberg et al. 1995; Roux et al. 1998), IgNARs rapidly raised important interest in the area of drug development. Indeed, the particular folding properties of V-NARs allow them to reach a large panel of protein sites, including hidden epitopes such as those found in the substrate pocket of enzymes that cannot be targeted by "classical" antibodies. Finally, V-NARs also present great solubility and stability, and their small size is another advantage within the field of antibody-based targeting strategy. Specific V-NARs from different elasmobranch species have already been developed to target viral proteins or toxins for medical applications such as anti-viral activity, immunodiagnostics or the development of biosensors. A list of these already-existing targeting V-NARs is available in the review from Kovaleva et al. (2014).

Within gnathostomes, camelids have also evolved such single-domain antibodies, from which the monomeric variable (V) antibody domain constitutes the VHH fragment. As they have been found only in sharks and camels so far, it is believed that these single-domain antibodies are the result of convergent evolution (Flajnik 2018). Nanobody is the name commonly used to indicate camelid $\mathrm{VHH}$ and shark V-NAR fragments. The important contribution that nanobodies can bring to the treatment of viral diseases has been spotlighted very recently, in the midst of the COVID19 pandemic. Wrapp et al. (2020) managed to produce VHH fragments able to prevent the spike (S) glycoprotein of several coronavirus (SARS-CoV-1, SARS-CoV-2 and MERS-CoV) from interacting with their cellular receptors.

\subsubsection{The Different Properties of Squalamine}

As mentioned, squalamine is a polyvalent molecule that also displays antiviral activity, an ability linked to its biochemical properties. The positive charge on account of the spermidine moiety of squalamine (Moore et al. 1993) provides it with high affinity for negatively charged phospholipids of the membrane lipid bilayer (Selinsky et al. 2000). As anionic phospholipids are important to regulate surface charge and protein localization (Yeung et al. 2008), the neutralization of negative charges by squalamine may lead to the disruption of electrostatic potential and shuffle membrane-anchored proteins. This has been demonstrated for Rac1, a GTPase used by many viruses during the process of cell entry, which might impact the viral replication cycle (Zasloff et al. 2011). In the same study, they observed that a wide range of viral pathogens (such as those responsible for dengue, yellow fever, equine encephalitis and Hepatitis B) exhibit variable susceptibility to squalamine in both in vitro and in vivo tests (Zasloff et al. 2011).

The ability of squalamine to interact with the negatively charged lipids of the cell membrane also represents the underlying mechanism of $\alpha$-synuclein aggregation impairment (Perni et al. 2017). These $\alpha$-synuclein aggregates are part of pathogenesis hallmarks of several neurodegenerative disorders, and their destruction constitutes an important challenge to limiting toxicity within the brain parenchyma. Perni et al. (2017) also showed that squalamine exposure led to motility recovery in an animal model of Parkinson disease.

Finally, squalamine has also been demonstrated to impede tumor-associated angiogenesis and the growth of several solid neoplasms (reviewed in Luer and Walsh 2018; MárquezGarbán et al. 2019). The mechanism of the angiostatic property of squalamine is not fully understood but might rely on, 
among other explanations, its ability to control endothelial cell shape/volume, as demonstrated by Sills et al. (1998) on embryonic vascular beds. More specifically, squalamine blocks the $\mathrm{Na}^{+} / \mathrm{H}^{+}$exchanger (isoform NHE3) (Akhter et al. 1999). Such inhibition of the sodium-hydrogen antiporter will result in the modification of the hydrogen efflux out of the cell, which can explain volume change of endothelial cells.

\subsubsection{Molecules Displaying Anti-Cancer Activity}

Lacking bone marrow, lymphatic system and nodes, elasmobranchs have evolved two particular lymphomyeloïd structures: the epigonal organ associated with the gonads and the Leydig organ located around the esophageal wall, as previously mentioned (Honma et al. 1984). They are involved in the production of red blood cells and play an important role in immune system function.

With the aim to better characterize cell function of these tissues, Walsh and Luer (2018) first showed that cells from the Leydig and epigonal organs display phagocytic and pinocytic activities (Luer and Walsh 2018). Next, looking for more specific bioactive compounds, they tested epigonal conditioned medium (prepared from adult bonnethead shark) and found that it was able to inhibit growth of several mammalian tumor cell lines (Walsh et al. 2006). More specifically on Jurkat T-cell lines, this medium induced caspase-mediated apoptosis (Walsh et al. 2013), but the biochemical nature of this (or these) cell death inducer(s) released from shark epigonal conditioned medium still has/have to be discovered.

As previously mentioned, blocking the neovascularization that accompanies tumor growth is another way to restrain malignancy progression. Besides squalamine, Neovastat (AE-941), a shark cartilage extract, has been shown to inhibit matrix metallopeptidase and VEGF activity (Falardeau et al. 2001; Béliveau et al. 2002), which is consistent with antiangiogenic property. More specifically, Zheng et al. (2007) isolated from the cartilage of the blue shark Prionace glauca, a $15.5 \mathrm{kDa}$ polypeptide (PG155) with the ability to reduce vessel formation in vertebrate embryos and tube formation of human umbilical vein endothelial cells (HUVECs). However, Neovastat hasn't gotten beyond phase II of clinical trials so far (Kang et al. 2019), meaning that the use of shark cartilage in the treatment of human malignancies is still exploratory.

\subsubsection{Evo-Devo Studies in the Search for the Origin of Skeleton and Brain Asymmetries}

\subsubsection{Endoskeleton and Bone-Like Tissue in Chondrichthyes}

Although skates, rays, sharks and chimeras are called cartilaginous fish, they possess mineralized structures in their endoskeleton and dermoskeleton (or exoskeleton). Their embryonic endoskeleton is made of a gel-like structure produced by chondrocytes: the hyaline cartilage, a cartilaginous matrix classically stained and observable using Alcian blue pigments. As development progresses, certain parts of the axial endoskeleton such as the vertebrae undergo mineralization, a process that can be visualized using Alizarin red staining.

Truncal vertebrae in elasmobranchs are made of i) a centrum that surrounds the notochord and ii) a dorsal neural arch delimiting the neural canal that contains the spinal cord. Caudal vertebrae also have, ventral to the centrum, a hemal arch that surrounds arteries and veins. Both the centrum and the neural arch of vertebrae of several elasmobranch species display Alcian blue staining at mid-embryogenesis, while Alizarin red coloration is observable in near-hatching embryos (Eames et al. 2007, Enault et al. 2015; Atake et al. 2019), meaning that a mineralization process is occurring on a cartilage-based matrix.

However, in contrast to the mineralization mechanism occurring in the long bones of Osteichthyes (the so-called endochondral ossification that also begins within cartilage but from the center to the periphery of the bone), the mineralization in elasmobranch vertebrae starts on the periphery of both the neural arch and the centrum. Interestingly, the expression pattern of type I and type II collagen in these elasmobranch structures is similar to that accompanying the shift from cartilage to mineralized cartilage during endochondral ossification of tetrapod long bones. Type II collagen (cartilage specific) is observed within the cartilaginous center of the neural arch, while type I collagen stains the outer surface of the neural arch (Eames et al. 2007; Enault et al. 2015). It is important, however, to outline that in several teleost species, some cartilages lack type II collagen expression, and bones can exhibit important immunostaining against type II collagen (Benjamin and Ralphs 1991). This indicates that the use of type II collagen as a pure cartilage marker must be considered cautiously.

Type X collagen is another collagen accompanying the process of endochondral ossification. Its expression was demonstrated in the mineralizing sites of catshark vertebrae but not in the type II collagen-expressing non-calcified elements (Debiais-Thibaud et al. 2019).

Another biochemical feature of mineralization is the presence of alkaline phosphatase (AP) activity that can be observed when the inner cartilage of tetrapod long bones is converted into a mineralized matrix. Such AP activity can also be detected in the mineralizing neural arches of nearhatching swell shark embryos (Eames et al. 2007).

Finally, Eames et al. (2007) described a specific cell population in the mineralizing sites of swell shark vertebrae that are morphologically different from chondrocytes, the rounded and well-separated cells embedded into the Alcian blue-positive matrix. These cells, located in the outer mineralizing layer of the neural arches, were surrounded by an Alizarin red-positive matrix and displayed an elongated shape (Eames et al. 2007). Similar flattened cells have been observed at the mineralizing sites of vertebrae in skates (Atake et al. 2019). The nature of these cells has not been investigated yet. Expression of signaling molecules (such as Ihh and several Wnt ligands) and transcription factors (mainly Sp7/Osterix and Runx2) known to be involved in the osteogenic program (Hartmann 2006) would be interesting to explore within the mineralizing elements of elasmobranchs. Such molecular studies would inform us about 
the mechanism underlying the calcification process in the elasmobranch axial endoskeleton and to what extent this mechanism shares genetic features with the one controlling endochondral ossification of the long bones in Osteichthyes. In the field of evo-devo, this last issue constitutes a fascinating question that can now be addressed, since functional experiments are possible (see Table 23.2) in several shark or skate species at different embryonic stages.

\subsubsection{Exoskeleton (Teeth and Dermal Denticles) in Chondrichthyes}

Teeth and dermal denticles (also named placoid or dermal scales) constitute the exoskeleton of Chondrichthyes. These mineralized appendages/structures made of enamel and dentine surrounding a pulp cavity are known under the general term of odontodes and can easily be observed in laboratories using Alizarin red staining. One important feature of elasmobranchs is that they are polyphyodont, meaning their teeth are continually replaced. The lower and upper jaws are lined by an initial row of mature individual teeth that can display several shapes (for example: needle-like, triangular or flattened). Posterior to this first line of teeth, multiple rows of developing teeth are present, intended to replace those that fall out. Unlike teeth, dermal denticles do not continuously regenerate throughout life. The dentition of holocephalans, the sister group of elasmobranchs, does not possess separate individual teeth but dental plates that grow continuously.

As with many other vertebrate embryonic structures, the development of teeth and dermal denticles involves reciprocal inductive interactions between an epithelium and its underlying mesenchyme, which are engineered by a set of signaling molecules and transcription factors. Using catshark models (Scyliorhinus stellaris and S. canicula), several works have demonstrated the expression of Shh, Wnt/ $\beta$-catenin, BMP and $F G F$ gene products in the developing dentition of these species, as reported in other bony vertebrates, which suggests that the dental gene regulatory network (GRN) is conserved within gnathostomes (Smith et al. 2009; Debiais-Thibaud et al. 2015; Martin et al. 2016; Rasch et al. 2016). However, the enamel knot, a transient signaling center present in the growing bud and controlling the morphogenesis of teeth cusps, seems to be missing in catshark teeth, indicating that the regulation point for cusp shape works differently in elasmobranchs (Debiais-Thibaud et al. 2015; Rasch et al. 2016).

BrdU pulse-chase experiments performed in embryonic and juvenile catsharks revealed the presence of slow cycling cells within the dental lamina, an epithelial tissue that interacts with the underlying mesenchyme and goes with tooth development (Martin et al. 2016; Vandenplas et al. 2016). These BrdU-positive cells that exhibit a low rate of mitosis constitute a stem cell population that expresses the Sox 2 marker (Martin et al. 2016).

Questioning the homology between teeth and dermal denticles, Debiais-Thibaud et al. (2011) investigated the expression of several $D l x$ genes, a family of transcription factors involved in the early specification of dental epithelium and mesenchyme, and found that catshark teeth and caudal primary scales share common expression of Dlx1, Dlx3, Dlx4 and Dlx 5 mRNAs. In addition, developing dermal scales in the catshark display the expression of signaling molecules such as BMP4, several FGFs and Shh (Debiais-Thibaud et al. 2015; Martin et al. 2016; Cooper et al. 2017). The conservation of the expression of this gene set supports the hypothesis that the appearance of additional odontodes on body surfaces or within cavities might be the result of a heterotopy, that is, of the dedicated gene regulatory network recruitment at this specific body part (Debiais-Thibaud et al. 2011; Martin et al. 2016).

In amniotes, integumentary structures such as feathers, hair and scales that also derive from epithelial placodes require FGF signaling for their development. FGF ligands are not only expressed in the developing dermal denticles in catsharks. In ovo injection of the FGF receptor inhibitor SU5402 leads to the perturbation of caudal dermal scale formation, indicating that this pathway is mandatory for their morphogenesis (Cooper et al. 2017). Such data also suggest that a common GRN might operate within the epithelial placodes of both amniote integumentary structures and elasmobranch dermal scales (Cooper et al. 2017).

Within the developing tooth or dermal denticle, enamel is produced by ameloblasts that differentiate from the epithelial compartment of the bud, while dentine is secreted by odontoblasts deriving from the mesenchymal compartment. Gillis et al. (2017) demonstrated that odontoblasts of the trunk denticles in the little skate (Leucoraja erinacea) are derived from trunk neural crest cells. This study constitutes one of the examples of successful cell-lineage tracing experiments in Chondrichthyes embryos (by means of DiI microinjection and staining). This work also shows that neural crest cells from the trunk can be skeletogenic, which is different from what has been reported in teleosts (Gillis et al. 2017).

An exhaustive discussion about the origin of teeth in vertebrates and their evolutionary relationship with odontodes in extinct or living species can be found in the recent review from Donoghue and Rücklin (2016).

\subsubsection{Evolution of Brain Asymmetries in Vertebrates}

The position of Chondrichthyes as the sister group of all bony vertebrates (Osteichthyes, Figure 23.1) undoubtedly makes cartilaginous fish species valuable to study the evolution of a biological structure or process. A recent example is the mechanism underlying asymmetry of the epithalamus, whose evolutionary history in gnathostomes has been brought to light thanks to an elasmobranch model.

The epithalamus arises from the dorsal part of the diencephalon and is composed of two habenular nuclei and a pineal complex (pineal and parapineal glands). In a great majority of vertebrate species, the habenular nuclei display left/right (L/R) asymmetries in size, neurotransmitter and developmental gene expression and in neuronal organization (Concha and Wilson 2001). In addition, while the pineal 
gland, involved in melatonin secretion, is generally located on the midline, the parapineal gland is found to be connected to the left habenulae and, in rare cases, to the right one (Boutet 2017). Finally, during zebrafish embryogenesis, the dorsal diencephalon displays a left-sided activity of the Nodal pathway known to be involved in L/R asymmetry of internal organs (Signore et al. 2009).

In zebrafish, the connection of the parapineal gland to the left habenula is important, as its experimental removal restores the symmetry of the two habenulae. In contrast, Nodal abrogation leads to randomized connection of the parapineal gland: it is either associated with the left habenula (50\% of the time) or the right (50\%). In other terms, asymmetry is still present, but laterality is lost (Signore et al. 2009).

The absence of data concerning Nodal expression outside the Osteichthyes group and the fact that the left-sided expression of Nodal in the diencephalon had been reported only in teleosts led to the hypothesis that L/R laterality of the epithalamus might have been stochastic at the base of the vertebrate lineage. Experiments performed with the catshark indicated, however, that Nodal is asymmetrically expressed in the dorsal diencephalon as in zebrafish and that it controls habenular asymmetries, including neurogenic asymmetry (Lagadec et al. 2015; Lagadec et al. 2018). Similar results are obtained using lamprey embryos (cyclostome/ agnatha; Lagadec et al. 2015). These findings obtained from jawless vertebrates and from Chondrichthyes demonstrate that epithalamic asymmetry was not random in the last common ancestor of vertebrates and that diencephalic leftsided Nodal expression was already present in this ancestor. Chondrichthyes, and also cyclostomes, thus allowed to understand the evolution of the mechanisms driving this particular brain asymmetry (Boutet 2017).

Note that evolutionary scenarios dealing with brain asymmetry or other processes are never set in stone and can be redrafted later on in light of data collected from additional species. This last point highlights the importance for experimental biology to diversify its models as much as possible. Much more than bringing complexity, embryonic and molecular results raised from a wide range of models, scattered over several taxa, contribute to broadening our view related to evolutionary mechanisms. Data obtained from fossil records are also very useful in such a kind of study.

\subsubsection{The Elasmobranch Properties of Kidney Regeneration}

As previously mentioned, elasmobranch fish have been found to possess a regenerative kidney. In 2003, Elger et al. described a nephrogenic zone in the adult kidneys of the little skate, Leucoraja erinacea. This nephrogenic zone represents a niche within the kidney where stem cell-like cells could reside. The tissue responds to partial reduction of renal mass with the formation of new nephrons. The morphogenic process of neonephrogenesis appears to be an important mechanism for renal growth, as well as for repair of injured kidneys. Renal hypertrophy (a common response to renal mass reduction in humans) contributed only slightly to the reconstitution of the little skate renal mass following the renal reduction experiment (Elger et al. 2003). The morphological analyses demonstrated that a zone of embryonic renal tissue persists in adult skates (Elger et al. 2003). $S$. canicula, S. acanthias and L. erinacea have been powerful models for the description of kidney morphogenesis, and multiple studies have detailed renal morphogenesis and architecture using sections (Hentschel 1987; Hentschel 1991; Elger et al. 2003; Cutler et al. 2012). This neonephrogenetic ability found in Chondrichthyes is a valuable framework which warrants studies on stem cell homeostasis during nephron ontogeny or repair.

As a conclusion, it appears that Chondrichthyes have accompanied experimental biology for a long time. The place they occupy in the vertebrate phylogenetic tree and their particular physiological and biological properties, such as the possibility to regenerate the adult kidney, to replace teeth continually or the unique structure of their antibodies make cartilaginous fish metazoans of great interest.

Human impact on Earth's ecosystems remains, however, overwhelming and a great threat to hundreds of Chondrichthyes species. Conservation status has to be taken into account when choosing a model for experimental studies if we want cartilaginous fish to continue to reveal new secrets for the next decades and beyond.

\section{ACKNOWLEDGMENTS}

We thank Nicole Guyard from the SBR library, Wilfried Thomas from the marine diving facility of the SBR and all the people at the Roscoff Aquarium Service (RAS) for their valuable help. We are also grateful to David Wahnoun and Haley Flom from the Erasmus+ funded project, DigitalMarine. Research in the laboratory is funded by Sorbonne Universités Emergence Grant [SU-16-R-EMR610_Seakidstem] (IDEX SUPER), and the "Ligue contre le Cancer" (Grand Ouest)]. Y.L.-R. is a student funded by Sorbonne Université (Ecole doctorale Complexité du Vivant ED515).

\section{BIBLIOGRAPHY}

Aidan, M.R., Hammerschalg, N., Collier, R.S. and Fallows, C. 2005. Predatory behaviour of white sharks (Carcharodon carcharias) at Seal Island, South Africa. J. Mar. Biol. UK 85: 1121-1135.

Akhter, S., Nath, S.K., Tse, C.M., Williams, J., Zasloff, M. and Donowitz, M. 1999. Squalamine, a novel cationic steroid, specifically inhibits the brush-border $\mathrm{Na}^{+} / \mathrm{H}^{+}$exchanger isoform NHE3. Am. J. Physiol. 276: C136-144.

Atake, O., Cooper, D.M.L. and Eames, B.F. 2019. Bone-like features in skate suggest a novel elasmobranch synapomorphy and deep homology of trabecular mineralization patterns. Acta Biomater. 84: 424-436.

Atkinson, C.J.L., Martin, K.J., Fraser, G.J. and Collin, S.P. 2016. Morphology and distribution of taste papillae and oral 
denticles in the developing oropharyngeal cavity of the bamboo shark, Chiloscyllium punctatum. Biol. Open 5: 1759-1769.

Balfour, F.M. 1878. A Monograph on the Development of Elasmobranch Fishes. Hardpress, Miami.

Ballard, W.W., Mellinger, J. and Lechenault, H. 1993. A series of normal stages for development of Scyliorhinus canicula, the lesser spotted dogfish (Chondrichthyes: Scyliorhinidae). Journal of Experimental Zoology 267: 318-336

Bedore, C.N., Harris, L.L. and Kajiura, S.M. 2014. Behavioral responses of batoid elasmobranchs to prey-simulating electric fields are correlated to peripheral sensory morphology and ecology. Zoology 117: 95-103.

Béliveau, R., Gingras, D., Kruger, E.A., Lamy, S., Sirois, P., Simard, B., Sirois, M.G., Tranqui, L., Baffert, F., Beaulieu, E., Dimitriadou, V., Pépin, M.-C., Courjal, F., Ricard, I., Poyet, P., Falardeau, P., Figg, W.D. and Dupont, E. 2002. The antiangiogenic agent neovastat (AE-941) inhibits vascular endothelial growth factor-mediated biological effects. Clin. Cancer Res. Off. J. Am. Assoc. Cancer Res. 8: 1242-1250.

Bell, G. 2018. Shark Sanctuaries around the World. The Pew Charitable Trust, Philadelphia, PA.

Benjamin, M. and Ralphs, J.R. 1991. Extracellular matrix of connective tissues in the heads of teleosts. J. Anat. 179: 137-148.

Berio, F., Evin, A., Goudemand, N. and Debiais-Thibaud, M. 2020. The intraspecific diversity of tooth morphology in the large-spotted catshark Scyliorhinus stellaris: Insights into the ontogenetic cues driving sexual dimorphism. J Anat. 237:960-978.

Boussarie, G., Bakker, J., Wangensteen, O.S., Mariani, S., Bonnin, L., Juhel, J.-B., Kiszka, J.J., Kulbicki, M., Manel, S., Robbins, W.D., Vigliola, L. and Mouillot, D. 2018. Environmental DNA illuminates the dark diversity of sharks. Sci. Adv. 4.

Boutet, A. 2017. The evolution of asymmetric photosensitive structures in metazoans and the Nodal connection. Mech. Dev. 147: 49-60.

Brazeau, M.D. and Friedman, M. 2015. The origin and early phylogenetic history of jawed vertebrates. Nature 520: 490-497.

Bs, R., Af, A., Jr, K.J. and Reg, R. 2019. Microstructural morphology of dermal and oral denticles of the sharpnose sevengill shark Heptranchias perlo (Elasmobranchii: Hexanchidae), a deep-water species. Microsc. Res. Tech. 82: 1243-1248.

Buffon, G.-L.L. 1789. Histoire Naturelles de Poissons. L'imprimerie Royale, Paris.

Burger, J.W. and Hess, W.N. 1960. Function of the rectal gland in the spiny dogfish. Science 131: 670-671.

Cailliet, G.M., Andrews, A.H., Burton, E.J., Watters, D.L., Kline, D.E. and Ferry-Graham, L.A. 2001. Age determination and validation studies of marine fishes: Do deep-dwellers live longer? Exp. Gerontol. 36: 739-764.

Capapé, C., Vergne, Y., Guélorguet, O. and Quignard, J.P. 2008. Maturity, fecundity and occurrence of the smallspotted catshark Scyliorhinus canicula (Chondrichthyes: Scyliorhinidae) off the Languedocian caost (Southern France, north-western Mediterranean). Life Environ. 58: 47-55.

Carey, F.G., Scharold, J.V. and Kalmijn, A.J. 1990. Movements of blue sharks (Prionace glauca) in depth and course. Mar. Biol. 106: 329-342.

Castro, J.I. 2017. The origins and rise of shark biology in the 20th century. Mar. Fish. Rev. 78: 14-33.

Castro, J.I., Bubucis P.M. and Overstrom, N. 1988. The reproductive biology of the chain dogfish. Copeia. 3: 740-746.
Cavanagh, R.D., Camhi, M., Burgess, G.H., Cailliet, G.M., Fordham, S.V., Simpfendorfer, C.A. and Musick, J.A. 2005. Sharks, rays and chimaeras: The status of the chondrichthyan fishes (S.L. Folwer, ed.). IUCN. Gland, Switzerland and Cambridge, UK.

Chapman, D.D., Shivji, M.S., Louis, E., Sommer, J., Fletcher, H. and Prodöhl, P.A. 2007. Virgin birth in a hammerhead shark. Biol. Lett. 3: 425-427.

Claes, J.M., Aksnes, D.L. and Mallefet, J. 2010. Phantom hunter of the fjords: Camouflage by counterillumination in a shark (Etmopterus spinax). J. Exp. Mar. Biol. Ecol. 388: 28-32.

Claes, J.M., Ho, H.-C. and Mallefet, J. 2012. Control of luminescence from pygmy shark (Squaliolus aliae) photophores. $J$. Exp. Biol. 215: 1691-1699.

Claes, J.M., Nilsson, D.-E., Mallefet, J. and Straube, N. 2015. The presence of lateral photophores correlates with increased speciation in deep-sea bioluminescent sharks. R. Soc. Open Sci. 2: 150219.

Clifton, S., Amemiya, C.T., Barnes, D., Forrest, J.N., Mattingly, C., Mardis, E., Minx, P., Waren, W. and Wilson, R.K. 2005. Proposal to sequence the genomes of the spiny dogfish shark (Squalus acanthias) and the little skate (Raja erinacea). Washington University, Genome Sequencing Center. Available at https://www.genome.gov/Pages/Research/ Sequencing/SeqProposals/SharkSkateSeq.pdf

Coates, M.I., Finarelli, J.A., Sansom, I.J., Andreev, P.S., Criswell, K.E., Tietjen, K., Rivers, M.L. and La Riviere, P.J. 2018. An early chondrichthyan and the evolutionary assembly of a shark body plan. Proc. R. Soc. B 285: 20172418.

Collin, S.P. 2012. The neuroecology of cartilaginous fishes: Sensory strategies for survival. Brain. Behav. Evol. 80: 80-96.

Collin, S.P., Lisney, T.J. and Hart, N.S. 2006. Visual communication in elasmobranchs. In: Communication in Fishes. Science Publishers Inc., Enfield, NH and Plymouth, UK.

Compagno, L.J.V. 1990. Alternative life-history styles of cartilaginous fishes in time and space. Environ. Biol. Fishes 28: 33-75.

Compagnucci, C., Debiais-Thibaud, M., Coolen, M., Fish, J., Griffin, J.N., Bertocchini, F., Minoux, M., Rijli, F.M., Borday-Birraux, V., Casane, D., Mazan, S. and Depew, M.J. 2013. Pattern and polarity in the development and evolution of the gnathostome jaw: Both conservation and heterotopy in the branchial arches of the shark, Scyliorhinus canicula. Dev. Biol. 377: 428-448.

Concha, M.L. and Wilson, S.W. 2001. Asymmetry in the epithalamus of vertebrates. J. Anat. 199: 63-84.

Coolen, M., Menuet, A., Chassoux, D., Compagnucci, C., Henry, S., Lévèque, L., Silva, C.D., Gavory, F., Samain, S., Wincker, P., Thermes, C., D'Aubenton-Carafa, Y., Rodriguez-Moldes, I., Naylor, G., Depew, M., Sourdaine, P. and Mazan, S. 2008. The dogfish Scyliorhinus canicula: A reference in jawed vertebrates. Cold Spring Harb. Protoc. 2008: pdb.emo111.

Coolen, M., Sauka-Spengler, T., Nicolle, D., Le-Mentec, C., Lallemand, Y., Silva, C.D., Plouhinec, J.-L., Robert, B., Wincker, P., SHI, D.-L. and Mazan, S. 2007. Evolution of axis specification mechanisms in jawed vertebrates: Insights from a chondrichthyan. PLoS One 2: e374.

Cooper, R.L., Martin, K.J., Rasch, L.J. and Fraser, G.J. 2017. Developing an ancient epithelial appendage: FGF signalling regulates early tail denticle formation in sharks. Evo Devo 8.

Cooper, R.L., Thiery, A.P., Fletcher, A.G., Delbarre, D.J., Rasch, L.J. and Fraser, G.J. 2018. An ancient Turing-like patterning 
mechanism regulates skin denticle development in sharks. Sci. Adv. 4: eaau5484.

Corlett, R.T. 2017. A bigger toolbox: Biotechnology in biodiversity conservation. Trends Biotechnol. 35: 55-65.

Couch, J. 1863. A History of the Fishes of the British Islands. Groombridge and sons. London, UK.

Cutler, C.P., Harmon, S., Walsh, J. and Burch, K. 2012. Characterization of aquaporin 4 protein expression and localization in tissues of the dogfish (Squalus acanthias). Front. Physiol. 3.

da Silva, N.J., Clementino Ferreira, K.R., Leite Pinto, R.N. and Aird, S.D. 2015. A severe accident caused by an ocellate river stingray (Potamotrygon motoro) in Central Brazil: How well do we really understand stingray venom chemistry, envenomation, and therapeutics? Toxins 7: 2272-2288.

Davis, S.P., Finarelli, J.A. and Coates, M.I. 2012. Acanthodes and shark-like conditions in the last common ancestor of modern gnathostomes. Nature 486: 247-250.

Dean, M.N., Mull, C.G., Gorb, S.N. and Summers, A.P. 2009. Ontogeny of the tessellated skeleton: Insight from the skeletal growth of the round stingray Urobatis halleri. J Anat. 215: 227-239.

Debiais-Thibaud, M., Chiori, R., Enault, S., Oulion, S., Germon, I., Martinand-Mari, C., Casane, D. and Borday-Birraux, V. 2015. Tooth and scale morphogenesis in shark: An alternative process to the mammalian enamel knot system. $B M C$ Evol. Biol. 15.

Debiais-Thibaud, M., Oulion, S., Bourrat, F., Laurenti, P., Casane, D. and Borday-Birraux, V. 2011. The homology of odontodes in gnathostomes: Insights from Dlx gene expression in the dogfish, Scyliorhinus canicula. BMC Evol. Biol. 11: 307.

Debiais-Thibaud, M., Simion, P., Ventéo, S., Muñoz, D., Marcellini, S., Mazan, S. and Haitina, T. 2019. Skeletal mineralization in association with type $\mathrm{X}$ collagen expression is an ancestral feature for jawed vertebrates. Mol. Biol. Evol. 36: 2265-2276.

De Iuliis, G. and Pulerà, D. 2019. Chapter 3: The Shark. In: The Dissection of Vertebrates (Third Edition) (G. De Iuliis and D. Pulerà, eds.), pp. 53-109. Academic Press, Boston.

Demski, L.S. and Wourms, J.P. 2013. The Reproduction and Development of Sharks, Skates, Rays and Ratfishes. Springer Science \& Business Media, New York, NY.

Diatta, Y. 2000. Reproductive biology of the common torpedo, Torpedo torpedo (Linnaeus, 1758) (Pisces, Torpedinidae) from the coast of Senegal (Eastern Tropical Atlantic). Available at: https://core.ac.uk/reader/39078552.

Didier, D.A. 1998. Embryonic staging and external features of development of the Chimaroid fish, Callorhincus milii (Holocephali, Callorhinchidae). J. Morphol. 236: 25-47.

Donoghue, P.C.J. and Rücklin, M. 2016. The ins and outs of the evolutionary origin of teeth. Evol. Dev. 18: 19-30.

Douglas, R. and Djamgoz, M. 2012. The Visual System of Fish. Springer Science \& Business Media, New York, NY.

Dudgeon, C.L., Coulton, L., Bone, R., Ovenden, J.R. and Thomas, S. 2017. Switch from sexual to parthenogenetic reproduction in a zebra shark. Sci. Rep. 7: 40537.

Dulvy, N.K., Fowler, S.L., Musick, J.A., Cavanagh, R.D., Kyne, P.M., Harrison, L.R., Carlson, J.K., Davidson, L.N., Fordham, S.V., Francis, M.P., Pollock, C.M., Simpfendorfer, C.A., Burgess, G.H., Carpenter, K.E., Compagno, L.J., Ebert, D.A., Gibson, C., Heupel, M.R., Livingstone, S.R., Sanciangco, J.C., Stevens, J.D., Valenti, S. and White, W.T. 2014. Extinction risk and conservation of the world's sharks and rays. eLife 3: e00590.
Dulvy, N.K. and Reynolds, J.D. 1997. Evolutionary transitions among egg-laying, live-bearing and maternal inputs in sharks and rays. Proc. R. Soc. B Biol. Sci. 264: 1309-1315.

Eames, B.F., Allen, N., Young, J., Kaplan, A., Helms, J.A. and Schneider, R.A. 2007. Skeletogenesis in the swell shark Cephaloscyllium ventriosum. J. Anat. 210: 542-554.

Elger, M., Hentschel, H., Litteral, J., Wellner, M., Kirsch, T., Luft, F.C. and Haller, H. 2003. Nephrogenesis is induced by partial nephrectomy in the elasmobranch Leucoraja erinacea. $J$. Am. Soc. Nephrol. 14: 1506-1518.

Enault, S., Muñoz, D.N., Silva, W.T.A.F., Borday-Birraux, V., Bonade, M., Oulion, S., Ventéo, S., Marcellini, S. and Debiais-Thibaud, M. 2015. Molecular footprinting of skeletal tissues in the catshark Scyliorhinus canicula and the clawed frog Xenopus tropicalis identifies conserved and derived features of vertebrate calcification. Front. Genet. 6.

Espinoza, M., Cappo, M., Heupel, M.R., Tobin, A.J. and Simpfendorfer, C.A. 2014. Quantifying shark distribution patterns and species-habitat associations: Implications of marine park zoning. PLoS One 9: e106885.

Falardeau, P., Champagne, P., Poyet, P., Hariton, C. and Dupont, E. 2001. Neovastat, a naturally occurring multifunctional antiangiogenic drug, in phase III clinical trials. Semin. Oncol. 28: 620-625.

Feulner, P.G.D., Plath, M., Engelmann, J., Kirschbaum, F. and Tiedemann, R. 2009. Electrifying love: Electric fish use speciesspecific discharge for mate recognition. Biol. Lett. 5: 225-228.

Fields, A.T., Feldheim, K.A., Poulakis, G.R. and Chapman, D.D. 2015. Facultative parthenogenesis in a critically endangered wild vertebrate. Curr. Biol. 25: R446-R447.

Flajnik, M.F. 2018. A cold-blooded view of adaptive immunity. Nat. Rev. Immunol. 18: 438-453.

Fonseca, E.S.S., Ruivo, R., Machado, A.M., Conrado, F., Tay, B.-H., Venkatesh, B., Santos, M.M. and Castro, L.F.C. 2019. Evolutionary plasticity in detoxification gene modules: The preservation and loss of the pregnane $\mathrm{X}$ receptor in Chondrichthyes lineages. Int. J. Mol. Sci. 20: 2331.

Forrest, J.N. 2016. The shark rectal gland model: A champion of receptor mediated chloride secretion through CFTR. Trans. Am. Clin. Climatol. Assoc. 127: 162-175.

Furumitsu, K., Wyffels, J.T. and Yamaguchi, A. 2019. Reproduction and embryonic development of the red stingray Hemitrygon akajei from Ariake Bay, Japan. Ichtyol. Res. 66: 419-436.

Gaillard, A.-L., Tay, B.-H., Pérez Sirkin, D.I., Lafont, A.-G., De Flori, C., Vissio, P.G., Mazan, S., Dufour, S., Venkatesh, B. and Tostivint, H. 2018. Characterization of gonadotropinreleasing hormone $(\mathrm{GnRH})$ genes from cartilaginous fish: Evolutionary perspectives. Front. Neurosci. 12: 607.

García, V.B., Lucifora, L.O. and Myers, R.A. 2008. The importance of habitat and life history to extinction risk in sharks, skates, rays and chimaeras. Proc. R. Soc. B Biol. Sci. 275: 83-89.

Gardiner, J.M. 2012. Sensory physiology and behavior of elasmobranchs. In: Biology of Sharks and Their Relatives. CRC Press, Boca Raton, FL.

Gardiner, J.M. and Atema, J. 2007. Sharks need the lateral line to locate odor sources: Rheotaxis and eddy chemotaxis. J. Exp. Biol. 210: 1925-1934.

Gardiner, J.M. and Atema, J. 2010. The function of bilateral odor arrival time differences in olfactory orientation of sharks. Curr. Biol. CB 20: 1187-1191.

Giles, S., Friedman, M. and Brazeau, M.D. 2015. Osteichthyan-like cranial conditions in an Early Devonian stem gnathostome. Nature 520: 82-85. 
Gillis, J.A., Alsema, E.C. and Criswell, K.E. 2017. Trunk neural crest origin of dermal denticles in a cartilaginous fish. Proc. Natl. Acad. Sci. 114: 13200-13205.

Gillis J.A. and Hall, B.K. 2016. A shared role for Sonic Hedgehog signaling in patterning chondrichthyan gill arch appendages and tetrapod limbs. Dev. 143: 1313-1317.

Glasauer, S.M.K. and Neuhauss, S.C.F. 2014. Whole-genome duplication in TELEOST fishes and its evolutionary consequences. Mol. Genet. Genomics MGG 289: 1045-1060.

Godard, B.G., Coolen, M., Le Panse, S., Gombault, A., FerreiroGalve, S., Laguerre, L., Lagadec, R., Wincker, P., Poulain, J., Da Silva, C., Kuraku, S., Carre, W., Boutet, A. and Mazan, S. 2014. Mechanisms of endoderm formation in a cartilaginous fish reveal ancestral and homoplastic traits in jawed vertebrates. Biol. Open 3: 1098-1107.

Greenberg, A.S., Avila, D., Hughes, M., Hughes, A., McKinney, E.C. and Flajnik, M.F. 1995. A new antigen receptor gene family that undergoes rearrangement and extensive somatic diversification in sharks. Nature 374: 168-173.

Gross, M. 2019. Stop the global slaughter of sharks. Curr. Biol. 29: R819-R822.

Gruber, D.F., Loew, E.R., Deheyn, D.D., Akkaynak, D., Gaffney, J.P., Smith, W.L., Davis, M.P., Stern, J.H., Pieribone, V.A. and Sparks, J.S. 2016. Biofluorescence in catsharks (Scyliorhinidae): Fundamental description and relevance for elasmobranch visual ecology. Sci. Rep. 6: 1-16.

Gruber, S.H. and Myrberg, A.A. 1977. Approaches to the study of the behavior of sharks. Am. Zool. 17: 471-486.

Guttridge, T.L., van Dijk, S., Stamhuis, E.J., Krause, J., Gruber, S.H. and Brown, C. 2013. Social learning in juvenile lemon sharks, Negaprion brevirostris. Anim. Cogn. 16: 55-64.

Halstead, B.W. and Bunker, N.C. 1952. The venom apparatus of the ratfish, Hydrolagus colliei. Copeia 1952: 128-138.

Hammerschlag, N. 2016. Nocturnal and crepuscular behavior in elasmobranchs: A review of movement, habitat use, foraging, and reproduction in the dark. Bull. Mar. Sci. doi: 10.5343/ bms.2016.1046.

Hara, Y., Yamaguchi, K., Onimaru, K., Kadota, M., Koyanagi, M., Keeley, S.D., Tatsumi, K., Tanaka, K., Motone, F., Kageyama, Y., Nozu, R., Adachi, N., Nishimura, O., Nakagawa, R., Tanegashima, C., Kiyatake, I., Matsumoto, R., Murakumo, K., Nishida, K., Terakita, A., Kuratani, S., Sato, K., Hyodo, S. and Kuraku, S. 2018. Shark genomes provide insights into elasmobranch evolution and the origin of vertebrates. Nat. Ecol. Evol. 2: 1761-1771.

Hart, N.S., Lisney, T.J., Marshall, N.J. and Collin, S.P. 2004. Multiple cone visual pigments and the potential for trichromatic colour vision in two species of elasmobranch. J. Exp. Biol. 207: 4587-4594.

Hartmann, C. 2006. A Wnt canon orchestrating osteoblastogenesis. Trends Cell Biol. 16: 151-158.

Hentschel, H. 1987. Renal architecture of the dogfish Scyliorhinus caniculus (Chondrichthyes, Elasmobranchii). Zoomorphology 107: 115-125.

Hentschel, H. 1991. Developing nephrons in adolescent dogfish, Scyliorhinus caniculus (L.), with reference to ultrastructure of early stages, histogenesis of the renal countercurrent system, and nephron segmentation in marine elasmobranchs. Am. J. Anat. 190: 309-333.

Holland, K.N., Wetherbee, B.M., Lowe, C.G. and Meyer, C.G. 1999. Movements of tiger sharks (Galeocerdo cuvier) in coastal Hawaiian waters. Mar. Biol. 134: 665-673.

Honma, Y., Okabe, K. and Chiba, A. 1984. Comparative histology of the Leydig and epigonal organs in some elasmobranchs. Jpn. J. Ichthyol. 31: 47-54.
Hubbs, C.L., Iwai, T. and Matsubara, K. 1967. External and Internal Characters, Horizontal and Vertical Distribution, Luminescence, and Food of the Dwarf Pelagic Shark, Euprotomicrus Bispinatus. University of California Press, Berkeley and Los Angeles, LA.

Hwang, J.-H., Parton, A., Czechanski, A., Ballatori, N. and Barnes, D. 2008. Arachidonic acid-induced expression of the organic solute and steroid transporter-beta (Ost-beta) in a cartilaginous fish cell line. Comp. Biochem. Physiol. Toxicol. Pharmacol. CBP 148: 39-47.

Inoue, J.G., Miya, M., Lam, K., Tay, B.-H., Danks, J.A., Bell, J., Walker, T.I. and Venkatesh, B. 2010. Evolutionary origin and phylogeny of the modern holocephalans (Chondrichthyes: Chimaeriformes): A mitogenomic perspective. Mol. Biol. Evol. 27: 2576-2586.

IUCN SSC Shark Specialist Group, C.M. (IUCN S.S.S.G., Javier Guallart (IUCN SSC Shark Specialist Group), Ferid Haka (IUCN SSC Shark Specialist Group), Titian Schembri (IUCN SSC Shark Specialist Group), Nicola Ungaro (IUCN SSC Shark Specialist Group), Jim Ellis (IUCN SSC Shark Specialist Group), Abella, A. and Kirsteen, M. 2014. IUCN red list of threatened species: Small spotted catshark. In: IUCN Red List of Threatened Species. Gland, Switzerland and Cambridge, UK.

Jennings, D.E., Gruber, S.H., Franks, B.R., Kessel, S.T. and Robertson, A.L. 2008. Effects of large-scale anthropogenic development on juvenile lemon shark (Negaprion brevirostris) populations of Bimini, Bahamas. Environ. Biol. Fishes 83: $369-377$.

Jordan, L.K. 2008. Comparative morphology of stingray lateral line canal and electrosensory systems. J. Morphol. 269: 1325-1339.

Jordan, L.K., Mandelman, J.W., McComb, D.M., Fordham, S.V., Carlson, J.K. and Werner, T.B. 2013. Linking sensory biology and fisheries bycatch reduction in elasmobranch fishes: A review with new directions for research. Conserv. Physiol. 1.

Joung, S.-J., Chen, C.-T., Clark, E., Uchida, S. and Huang, W.Y.P. 1996. The whale shark, Rhincodon typus, is a livebearer: 300 embryos found in one 'megamamma' supreme. Environ. Biol. Fishes 46: 219-223.

Jung H., Baek M., D’Elia, K.P., Boisvert C., Currie P.D., Tay B.H., Venkatesh B., Brown S.M., Heguy A., Schoppik D. and Dasen, J.S. 2018. The ancient origins of neural substrates for land walking. Cell. 172: 667-682.

Kang, B., Park, H. and Kim, B. 2019. Anticancer activity and underlying mechanism of phytochemicals against multiple myeloma. Int. J. Mol. Sci. 20.

Kastschenko, N. 1888. Zur Entwicklungsgeschichte des Selachierembryos. Anat Anz 3: 445-467.

Kelly, M.L., Collin, S.P., Hemmi, J.M. and Lesku, J.A. 2019. Evidence for sleep in sharks and rays: Behavioural, physiological, and evolutionary considerations. Brain. Behav. Evol. 94: 37-50.

Kimber, J.A., Sims, D.W., Bellamy, P.H. and Gill, A.B. 2014. Elasmobranch cognitive ability: Using electroreceptive foraging behaviour to demonstrate learning, habituation and memory in a benthic shark. Anim. Cogn. 17: 55-65.

King, B.L., Gillis, J.A., Carlisle, H.R. and Dahn, R.D. 2011. A natural deletion of the HoxC cluster in elasmobranch fishes. Science 334: 1517.

Klimley, A.P. 1993. Highly directional swimming by scalloped hammerhead sharks, Sphyrna lewini, and subsurface irradiance, temperature, bathymetry, and geomagnetic field. Mar. Biol. 117: 1-22.

Kovaleva, M., Ferguson, L., Steven, J., Porter, A. and Barelle, C. 2014. Shark variable new antigen receptor biologics: A 
novel technology platform for therapeutic drug development. Expert Opin. Biol. Ther. 14: 1527-1539.

Kuba, M.J., Byrne, R.A. and Burghardt, G.M. 2010. A new method for studying problem solving and tool use in stingrays (Potamotrygon castexi). Anim. Cogn. 13: 507-513.

Kuraku, S. 2021. Shark and ray genomics for disentangling their morphological diversity and vertebrate evolution. Dev Biol. 477: 262-272

Lagadec, R., Laguerre, L., Menuet, A., Amara, A., Rocancourt, C., Péricard, P., Godard, B.G., Celina Rodicio, M., RodriguezMoldes, I., Mayeur, H., Rougemont, Q., Mazan, S. and Boutet, A. 2015. The ancestral role of nodal signalling in breaking L/R symmetry in the vertebrate forebrain. Nat. Commun. 6: 6686.

Lagadec, R., Lanoizelet, M., Sánchez-Farías, N., Hérard, F., Menuet, A., Mayeur, H., Billoud, B., Rodriguez-Moldes, I., Candal, E. and Mazan, S. 2018. Neurogenetic asymmetries in the catshark developing habenulae: Mechanistic and evolutionary implications. Sci. Rep. 8: 4616.

Lee, A.P., Kerk, S.Y., Tan, Y.Y., Brenner, S. and Venkatesh, B. 2011. Ancient vertebrate conserved noncoding elements have been evolving rapidly in teleost fishes. Mol. Biol. Evol. 28: 1205-1215.

Li, C., Matthes-Rosana, K.A., Garcia, M. and Naylor, G.J.P. 2012. Phylogenetics of chondrichthyes and the problem of rooting phylogenies with distant outgroups. Mol. Phylogenet. Evol. 63: 365-373.

Lisney, T.J. 2010. A review of the sensory biology of chimaeroid fishes (Chondrichthyes: Holocephali). Rev. Fish Biol. Fish. 20: 571-590.

López-Romero, F.A., Klimpfinger, C., Tanaka, S. and Kriwet, J. 2020. Growth trajectories of prenatal embryos of the deepsea shark Chlamydoselachus anguineus (Chondrichthyes). J. Fish. Biol. 97: 212-224.

Luer, C.A. and Walsh, C.J. 2018. Potential human health applications from marine biomedical research with elasmobranch fishes. Fishes 3: 47.

Luer, C.A., Walsh, C.J., Bodine, A.B. and Wyffels, J.T. 2007. Normal embryonic development in the clearnose skate, Raja eglanteria, with experimental observations on artificial insemination. Environ. Biol. Fishes 80: 239.

Lyons, K. and Wynne-Edwards, K.E. 2018. Legacy polychlorinated biphenyl contamination impairs male embryonic development in an elasmobranch with matrotrophic histotrophy, the round stingray (Urobatis halleri). Environ. Toxicol. Chem. 37: 2904-2911.

Márquez-Garbán, D.C., Gorrín-Rivas, M., Chen, H.-W., Sterling, C., Elashoff, D., Hamilton, N. and Pietras, R.J. 2019. Squalamine blocks tumor-associated angiogenesis and growth of human breast cancer cells with or without HER-2/ neu overexpression. Cancer Lett. 449: 66-75.

Marra, N.J., Stanhope, M.J., Jue, N.K., Wang, M., Sun, Q., Pavinski Bitar, P., Richards, V.P., Komissarov, A., Rayko, M., Kliver, S., Stanhope, B.J., Winkler, C., O'Brien, S.J., Antunes, A., Jorgensen, S. and Shivji, M.S. 2019. White shark genome reveals ancient elasmobranch adaptations associated with wound healing and the maintenance of genome stability. Proc. Natl. Acad. Sci. U. S. A. 116: 4446-4455.

Martin, A.P., Naylor, G.J.P. and Palumbi, S.R. 1992. Rates of mitochondrial DNA evolution in sharks are slow compared with mammals. Nature 357: 153-155.

Martin, K.J., Rasch, L.J., Cooper, R.L., Metscher, B.D., Johanson, Z. and Fraser, G.J. 2016. Sox $2+$ progenitors in sharks link taste development with the evolution of regenerative teeth from denticles. Proc. Natl. Acad. Sci. 113: 14769-14774.
Maruska, K.P. 2001. Morphology of the mechanosensory lateral line system in elasmobranch fishes: Ecological and behavioral considerations. Environ. Biol. Fishes 60: 47-75.

Mattingly, C., Parton, A., Dowell, L., Rafferty, J. and Barnes, D. 2004. Cell and molecular biology of marine elasmobranchs: Squalus acanthias and Raja erinacea. Zebrafish 1: 111-120.

Mattisson, A. and Faänge, R. 1982. The cellular structure of the Leydig organ in the shark, Etmopterus spinax (1.). Biol. Bull. 162: 182-194.

Maxwell, E.E., Fröbisch, N.B. and Heppleston, A.C. 2008. Variability and conservation in late chondrichthyan development: Ontogeny of the winter skate (Leucoraja ocellata). Anat. Rec. 291: 1079-1087.

McClenachan, L., Cooper, A.B., Carpenter, K.E. and Dulvy, N.K. 2012. Extinction risk and bottlenecks in the conservation of charismatic marine species. Conserv. Lett. 5: 73-80.

McComb, D.M. and Kajiura, S.M. 2008. Visual fields of four batoid fishes: A comparative study. J. Exp. Biol. 211: 482-490.

Mellinger, J. 1994. L'œuf de roussette (Scyliorhinus canicula) incubé au labortatoire: un matériel de recherche pour l'embryologiste, l'éthologiste, le physiologiste. Ichtyophysiol. Acta. 17: 9-27.

Meyer, C.G., Holland, K.N. and Papastamatiou, Y.P. 2005. Sharks can detect changes in the geomagnetic field. J. R. Soc. Interface 2: 129-130.

Moore, K.S., Wehrli, S., Roder, H., Rogers, M., Forrest, J.N., McCrimmon, D. and Zasloff, M. 1993. Squalamine: An aminosterol antibiotic from the shark. Proc. Natl. Acad. Sci. U. S. A. 90: 1354-1358.

Motoyasu, M., Yoshiyuki, I., Shigenori, K., Haruyuki, I. and Tooru, I. 2003. Artificial insemination of the cloudy catshark. JAZA 44: 39-43.

Mull, C.G., Yopak, K.E. and Dulvy, N.K. 2011. Does more maternal investment mean a larger brain? Evolutionary relationships between reproductive mode and brain size in chondrichthyans. Mar. Freshw. Res. 62: 567.

Mulley, J.F., Hargreaves, A.D., Hegarty, M.J., Heller, R.S. and Swain, M.T. 2014. Transcriptomic analysis of the lesser spotted catshark (Scyliorhinus canicula) pancreas, liver and brain reveals molecular level conservation of vertebrate pancreas function. BMC Genomics 15.

Musa, S.M., Czachur M.V. and Shiels, H.A. 2018. Oviparous elasmobranch inside the egg case in 7 key stages. PLoS One. 13.

Myrberg, A.A. 2003. Cognition in elasmobranch fishes, a likely possibility. In: ResearchGate. Max Planck Institute, Tutzing, Germany.

Myrberg, A.A. 2001. The acoustical biology of elasmobranchs. Environ. Biol. Fishes 60: 31-46.

Nielsen, J., Hedeholm, R.B., Heinemeier, J., Bushnell, P.G., Christiansen, J.S., Olsen, J., Ramsey, C.B., Brill, R.W., Simon, M., Steffensen, K.F. and Steffensen, J.F. 2016. Eye lens radiocarbon reveals centuries of longevity in the Greenland shark (Somniosus microcephalus). Science 353: 702-704.

Onimaru, K., Tatsumi, K., Shibagaki, K. and Kuraku, S. 2018. A de novo transcriptome assembly of the zebra bullhead shark, Heterodontus zebra. Sci. Data 5: 1-5.

Oulion, S., Borday-Birraux, V., Debiais-Thibaud, M., Mazan, S., Laurenti, P. and Casane, D. 2011. Evolution of repeated structures along the body axis of jawed vertebrates, insights from the Scyliorhinus canicula Hox code. Evol. Dev. 13: 247-259.

Oulion, S., Debiais-Thibaud, M., d'Aubenton-Carafa, Y., Thermes, C., Da Silva, C., Bernard-Samain, S., Gavory, F., Wincker, P., Mazan, S. and Casane, D. 2010. Evolution of Hox gene clusters in gnathostomes: Insights from a survey of a shark 
(Scyliorhinus canicula) transcriptome. Mol. Biol. Evol. 27: 2829-2838.

Park, H.B., Lam, Y.C., Gaffney, J.P., Weaver, J.C., Krivoshik, S.R., Hamchand, R., Pieribone, V., Gruber, D.F. and Crawford, J.M. 2019. Bright green biofluorescence in sharks derives from bromo-kynurenine metabolism. iScience 19: 1291-1336.

Parker, G.H. 1914. The directive influence of the sense of smell in the dogfish. Bull. US. Bureau. Fish. 33: 61-68.

Parmentier, E., Banse, M., Boistel, R., Compère, P., Bertucci, F. and Colleye, O. 2020. The development of hearing abilities in the shark Scyliorhinus canicula. J. Anat. n/a.

Parton, A., Forest, D., Kobayashi, H., Dowell, L., Bayne, C. and Barnes, D. 2007. Cell and molecular biology of SAE, a cell line from the spiny dogfish shark, Squalus acanthias. Comp. Biochem. Physiol. Toxicol. Pharmacol. CBP 145: 111-119.

Patterson, C. 1981. Significance of fossils in determining evolutionary relationships. Annu. Rev. Ecol. Syst. 12: 195-223.

Perni, M., Galvagnion, C., Maltsev, A., Meisl, G., Müller, M.B.D., Challa, P.K., Kirkegaard, J.B., Flagmeier, P., Cohen, S.I.A., Cascella, R., Chen, S.W., Limbocker, R., Sormanni, P., Heller, G.T., Aprile, F.A., Cremades, N., Cecchi, C., Chiti, F., Nollen, E.A.A., Knowles, T.P.J., Vendruscolo, M., Bax, A., Zasloff, M. and Dobson, C.M. 2017. A natural product inhibits the initiation of $\alpha$-synuclein aggregation and suppresses its toxicity. Proc. Natl. Acad. Sci. U. S. A. 114: E1009-E1017.

Pradel, A., Maisey, J.G., Tafforeau, P., Mapes, R.H. and Mallatt, J. 2014. A Palaeozoic shark with osteichthyan-like branchial arches. Nature 509: 608-611.

Pratt, H.L. and Carrier, J.C. 2001. A review of elasmobranch reproductive behavior with a case study on the nurse shark, Ginglymostoma cirratum. Environ. Biol. Fishes 60: 157-188.

Ramírez-Amaro, S., Ordines, F., Esteban, A., García, C., Guijarro, B., Salmerón, F., Terrasa, B. and Massutí, E. 2020. The diversity of recent trends for chondrichthyans in the Mediterranean reflects fishing exploitation and a potential evolutionary pressure towards early maturation. Sci. Rep. 10: 1-18.

Rasch, L.J., Martin, K.J., Cooper, R.L., Metscher, B.D., Underwood, C.J. and Fraser, G.J. 2016. An ancient dental gene set governs development and continuous regeneration of teeth in sharks. Dev. Biol. 415: 347-370.

Read, T.D., Petit, R.A., Joseph, S.J., Alam, Md.T., Weil, M.R., Ahmad, M., Bhimani, R., Vuong, J.S., Haase, C.P., Webb, D.H., Tan, M. and Dove, A.D.M. 2017. Draft sequencing and assembly of the genome of the world's largest fish, the whale shark: Rhincodon typus Smith 1828. BMC Genomics 18: 532.

Renz, A.J., Meyer, A. and Kuraku, S. 2013. Revealing less derived nature of cartilaginous fish genomes with their evolutionary time scale inferred with nuclear genes. PLoS One 8: e66400.

Richards, V.P., Suzuki, H., Stanhope, M.J. and Shivji, M.S. 2013. Characterization of the heart transcriptome of the white shark (Carcharodon carcharias). BMC Genomics 14: 697.

Ritchie, K.B., Schwarz, M., Mueller, J., Lapacek, V.A., Merselis, D., Walsh, C.J. and Luer, C.A. 2017. Survey of antibioticproducing bacteria associated with the epidermal mucus layers of rays and skates. Front. Microbiol. 8.

Rosa, R., Baptista, M., Lopes, V.M., Pegado, M.R., Paula, J.R., Trübenbach, K., Leal, M.C., Calado, R. and Repolho, T. 2014. Early-life exposure to climate change impairs tropical shark survival. Proc. Biol. Sci. 281.

Rosa, R., Rummer, J.L. and Munday, P.L. 2017. Biological responses of sharks to ocean acidification. Biol. Lett. 13: 20160796.

Roux, K.H., Greenberg, A.S., Greene, L., Strelets, L., Avila, D., McKinney, E.C. and Flajnik, M.F. 1998. Structural analysis of the nurse shark (new) antigen receptor (NAR): Molecular convergence of NAR and unusual mammalian immunoglobulins. Proc. Natl. Acad. Sci. 95: 11804-11809.

Salazar, A. 2018. Advanced Chordate Zoology (First Edition). Ed-Tech Press, Waltham Abbey, UK.

Sauka-Spengler, T., Baratte, B., Lepage, M. and Mazan, S. 2003. Characterization of Brachyury genes in the dogfish S. canicula and the lamprey L. fluviatilis: Insights into gastrulation in a chondrichthyan. Dev. Biol. 263: 296-307.

Schluessel, V. 2015. Who would have thought that 'Jaws' also has brains? Cognitive functions in elasmobranchs. Anim. Cogn. 18: 19-37.

Schluessel, V. and Bleckmann, H. 2005. Spatial memory and orientation strategies in the elasmobranch Potamotrygon motoro. J. Comp. Physiol. A 191: 695-706.

Selinsky, B.S., Smith, R., Frangiosi, A., Vonbaur, B. and Pedersen, L. 2000. Squalamine is not a proton ionophore. Biochim. Biophys. Acta 1464: 135-141.

Sheldon, R.E. 1909. The reactions of the dogfish to chemical stimuli. J. Comp. Neurol. Psychol. 19: 273-311.

Sheldon, R.E. 1911. The sense of smell in Selachians. J. Exp. Zool. 10: 51-62.

Shiffman, D.S., Ajemian, M.J., Carrier, J.C., Daly-Engel, T.S., Davis, M.M., Dulvy, N.K., Grubbs, R.D., Hinojosa, N.A., Imhoff, J., Kolmann, M.A., Nash, C.S., Paig-Tran, E.W.M., Peele, E.E., Skubel, R.A., Wetherbee, B.M., Whitenack, L.B. and Wyffels, J.T. 2020. Trends in chondrichthyan research: An analysis of three decades of conference abstracts. Copeia 108: 122-131.

Signore, I.A., Guerrero, N., Loosli, F., Colombo, A., Villalón, A., Wittbrodt, J. and Concha, M.L. 2009. Zebrafish and medaka: Model organisms for a comparative developmental approach of brain asymmetry. Philos. Trans. R. Soc. B Biol. Sci. 364: 991-1003.

Sills, A. K., Williams, J. I., Tyler, B. M., Epstein, D. S., Sipos, E. P., Davis, J. D., McLane, M. P., Pitchford, S., Chesire, K., Gannon, F. H., Kinney, W. A., hao, T. L., Donowitz, M., Laterra, J., Zasloff, M. and Brem, H. 1998. Squalamine inhibits angiogenesis and solid tumor growth in vivo and perturbs embryonic vasculature. Cancer Res. 58:2784-2792.

Sims, D.W. 2019. 8.9 the significance of ocean deoxygenation for Elasmobranchs. Ocean deoxygenation: Everyone's problem; Causes, impacts, consequences and solution. Edited by D. Laffolry and JM Baxter. IUCN. Gland, Switzerland and Cambridge, UK.

Smith, M.M., Fraser, G.J., Chaplin, N., Hobbs, C. and Graham, A. 2009. Reiterative pattern of Sonic Hedgehog expression in the catshark dentition reveals a phylogenetic template for jawed vertebrates. Proc. R. Soc. B Biol. Sci. 276: $1225-1233$.

Sparks, J.S., Schelly, R.C., Smith, W.L., Davis, M.P., Tchernov, D., Pieribone, V.A. and Gruber, D.F. 2014. The covert world of fish biofluorescence: A phylogenetically widespread and phenotypically variable phenomenon. PLoS One 9.

Stedman, H.H., Kozyak, B.W., Nelson, A., Thesier, D.M., Su, L.T., Low, D.W., Bridges, C.R., Shrager, J.B., Minugh-Purvis, N. and Mitchell, M.A. 2004. Myosin gene mutation correlates with anatomical changes in the human lineage. Nature 428: 415-418.

Straube, N., Li, C., Claes, J.M., Corrigan, S. and Naylor, G.J.P. 2015. Molecular phylogeny of squaliformes and first occurrence of bioluminescence in sharks. BMC Evol. Biol. 15.

Sundström, L.F., Gruber, S.H., Clermont, S.M., Correia, J.P.S., de Marignac, J.R.C., Morrissey, J.F., Lowrance, C.R., Thomassen, 
L. and Oliveira, M.T. 2001. Review of elasmobranch behavioral studies using ultrasonic telemetry with special reference to the lemon shark, Negaprion brevirostris, around Bimini Islands, Bahamas. Environ. Biol. Fishes 60: 225-250.

Tanegashima, C., Nishimura, O., Motone, F., Tatsumi, K., Kadota, M. and Kuraku, S. 2018. Embryonic transcriptome sequencing of the ocellate spot skate Okamejei kenojei. Sci. Data 5: 1-6.

Theiss, S.M., Lisney, T.J., Collin, S.P. and Hart, N.S. 2007. Colour vision and visual ecology of the blue-spotted maskray, Dasyatis kuhlii Müller \& Henle, 1814. J. Comp. Physiol. A 193: 67-79.

Tomita, T., Murakumo, K., Miyamoto, K., Sato, K., Oka, S., Kamisako, H. and Toda, M. 2016. Eye retraction in the giant guitarfish, Rhynchobatus djiddensis (Elasmobranchii: Batoidea): A novel mechanism for eye protection in batoid fishes. Zoology 119: 30-35.

Tozer, H. and Dagit, D.D. 2004. Husbandry of spotted ratfish, Hydrolagus colliei. In: The Elasmobranch Husbandry Manual: Captive Care of Sharks, Rays and their Relatives, pp. 488-491. Ohio Biological Survey, Inc. Columbus, OH.

Tricas, T.C and Gruber, S.H. 2001. The Behavior and Sensory Biology of Elasmobranch Fishes: An Anthology in Memory of Donald Richard Nelson: Developments in Environmental Biology of Fishes. Kluwer Academic Publishers, Dordrecht, Netherlands.

Vandebroek, G. 1936. Les mouvements morphogénétiques au cours de la gastrulation chez Scyllium canicula Cuv. In: Archives de Biologie, pp. 499-582. Bruxelles.

Vandenplas, S., Vandeghinste, R., Boutet, A., Mazan, S. and Huysseune, A. 2016. Slow cycling cells in the continuous dental lamina of Scyliorhinus canicula: New evidence for stem cells in sharks. Dev. Biol. 413: 39-49.

Venkatesh, B., Kirkness, E.F., Loh, Y.-H., Halpern, A.L., Lee, A.P., Johnson, J., Dandona, N., Viswanathan, L.D., Tay, A., Venter, J.C., Strausberg, R.L. and Brenner, S. 2006. Ancient noncoding elements conserved in the human genome. Science 314: 1892-1892.

Venkatesh, B., Lee, A.P., Ravi, V., Maurya, A.K., Lian, M.M., Swann, J.B., Ohta, Y., Flajnik, M.F., Sutoh, Y., Kasahara, M., Hoon, S., Gangu, V., Roy, S.W., Irimia, M., Korzh, V., Kondrychyn, I., Lim, Z.W., Tay, B.-H., Tohari, S., Kong, K.W., Ho, S., Lorente-Galdos, B., Quilez, J., Marques-Bonet, T., Raney, B.J., Ingham, P.W., Tay, A., Hillier, L.W., Minx, P., Boehm, T., Wilson, R.K., Brenner, S. and Warren, W.C. 2014. Elephant shark genome provides unique insights into gnathostome evolution. Nature 505: 174-179.

Walls, G.L. 1942. The vertebrate eye and its adaptive radiation. Anat. Rec. 88: 411-413.

Walsh, C.J., Luer, C.A., Bodine, A.B., Smith, C.A., Cox, H.L., Noyes, D.R. and Maura, G. 2006. Elasmobranch immune cells as a source of novel tumor cell inhibitors: Implications for public health. Integr. Comp. Biol. 46: 1072-1081.

Walsh, C.J., Luer, C.A., Yordy, J.E., Cantu, T., Miedema, J., Leggett, S.R., Leigh, B., Adams, P., Ciesla, M., Bennett,
C. and Bodine, A.B. 2013. Epigonal conditioned media from bonnethead shark, Sphyrna tiburo, induces apoptosis in a T-cell leukemia cell line, jurkat E6-1. Mar. Drugs 11: 3224-3257.

Wegner, N.C. 2015. 3: Elasmobranch gill structure. In: Fish Physiology (R.E. Shadwick, A.P. Farrell and C.J. Brauner, eds.), pp. 101-151. Academic Press. Elsevier, Amsterdam, the Netherlands.

Wheeler, C.R., Gervais, C.R., Johnson, M.S., Vance, S., Rosa, R., Mandelman, J.W. and Rummer, J.L. 2020. Anthropogenic stressors influence reproduction and development in elasmobranch fishes. Rev. Fish Biol. Fish. 30: 373-386.

White, W.T. and Last, P.R. 2012. A review of the taxonomy of chondrichthyan fishes: A modern perspective. J. Fish Biol. 80: 901-917.

Wilga, C.D. and Lauder, G.V. 2002. Function of the heterocercal tail in sharks: Quantitative wake dynamics during steady horizontal swimming and vertical maneuvering. J. Exp. Biol. 205: 2365-2374.

Wotton, K.R., Mazet, F. and Shimeld, S.M. 2008. Expression of FoxC, FoxF, FoxL1, and FoxQ1 genes in the dogfish Scyliorhinus canicula defines ancient and derived roles for fox genes in vertebrate development. Dev. Dyn. 237: 1590-1603.

Wourms, J.P. 1997. The rise of fish embryology in the nineteenth century. Am. Zool. 37: 269-310.

Wrapp, D., De Vlieger, D., Corbett, K.S., Torres, G.M., Wang, N., Van Breedam, W., Roose, K., van Schie, L., Hoffmann, M., Pöhlmann, S., Graham, B.S., Callewaert, N., Schepens, B., Saelens, X. and McLellan, J.S. 2020. Structural basis for potent neutralization of betacoronaviruses by single-domain camelid antibodies. Cell 181: 1004-1015.e15.

Wueringer, B.E., Peverell, S.C., Seymour, J., L. Squire, J., Kajiura, S.M. and Collin, S.P. 2011. Sensory systems in sawfishes. 1: The ampullae of Lorenzini. Brain. Behav. Evol. 78: 139-149.

Wyffels, J., L. King, B., Vincent, J., Chen, C., Wu, C.H. and Polson, S.W. 2014. SkateBase, an elasmobranch genome project and collection of molecular resources for chondrichthyan fishes. F1000Research 3.

Yeung, T., Gilbert, G.E., Shi, J., Silvius, J., Kapus, A. and Grinstein, S. 2008. Membrane phosphatidylserine regulates surface charge and protein localization. Science 319: 210-213.

Zasloff, M., Adams, A.P., Beckerman, B., Campbell, A., Han, Z., Luijten, E., Meza, I., Julander, J., Mishra, A., Qu, W., Taylor, J.M., Weaver, S.C. and Wong, G.C.L. 2011. Squalamine as a broad-spectrum systemic antiviral agent with therapeutic potential. Proc. Natl. Acad. Sci. 108: 15978-15983.

Zheng, L., Ling, P., Wang, Z., Niu, R., Hu, C., Zhang, T. and Lin, X. 2007. A novel polypeptide from shark cartilage with potent anti-angiogenic activity. Cancer Biol. Ther. 6: 775-780.

Zhu, M., Yu, X., Ahlberg, P.E., Choo, B., Lu, J., Qiao, T., Qu, Q., Zhao, W., Jia, L., Blom, H. and Zhu, Y. 2013. A Silurian placoderm with osteichthyan-like marginal jaw bones. Nature 502: 188-193. 